\title{
Early Middle Frasnian platform reef strata in the Moravian Karst interpreted as recording the atmospheric dust changes: the key to understanding perturbations in the punctata conodont zone
}

\author{
JINDŘICH HLADIL, LEONA KOPTíKOVÁ, ARNOŠT GALLE, VÁClAV SEDLÁČEK, PETR PRUNER, \\ PETR SCHNABL, ANNA LANGROVÁ, ONDŘEJ BÁBEK, JAROSLAV FRÁNA, JANA HLADÍKOVÁ, \\ JIŘÍ OTAVA \& MILAN GERŠL
}

Development of new stratigraphic techniques has led to better understanding of the compositional variability and quantity of dust-related impurity components in pure marine limestones, with a considerable impact on stratigraphic resolution and explanation of causality. The early Middle Frasnian (E-MF, punctata Zone) stratigraphic interval was selected for this study in order to assess the contribution of atmospheric dust and to distinguish between the robust climatically driven anomalies and the potential distant effect of the Alamo impact. The location of the study in the Moravian Karst area has two advantages: there are no mixed carbonate-siliciclastic sediments, only the pure limestone of a platform reef complex, and the authors have access to voluminous survey and drilling reports. The methodology employed for undertaking the most recent research was based on succession and combination of the following steps: biostratigraphy and facies analysis, magnetic susceptibility (MS), gamma-ray spectrometry (GRS), instrumental neutron activation analysis (INAA), and finally, separation and assessment of rare non-carbonate particles. The natural atmospheric dust burden, deposition, and embedding in pure carbonate traps were, most likely, threefold higher during the Frasnian in the Upper Devonian in comparison with Quaternary platform reef counterparts. Variation of 10-100 ka averages is medium in terms of the Frasnian ranges of MS-GRS values, and the base and top of the E-MF interval are manifested by robust elevations of these values. Forced anomalies in MS, GRS and geochemical signals that defy the normal sequence of rhythms were found: two anomalies disturb the broad middle part of the E-MF interval and one is superimposed on the upper part of the punctata-hassi zones strata. The most significant disturbance was found near the mid-punctata Zone level. In spite of the relatively low magnitude, it shows features that are usually related to major environmental crises which occured in the Devonian, such as the Choteč, Kačák or Kellwasser events. These include a large depression in MS and dust-particle concentration values coupled with a period of sea level lowstand and calm atmospheric conditions (stage A), and an abrupt shift to high MS that has a comb-like pattern that gradually fades upward, developed together with a forced flooding surface, increased detritism, and stormy conditions (stage B). It is a reverse of the normal cyclicity in pure limestone when the high impurity corresponds to lowstands. A very small amount of particulate material of an exotic nature was found at the A-B stage interface and assessed: it contained iron-rich silicate microspherules and drops, devitrified glasses, tiny mineral/rock clasts of hyperbasite compositions, as well as pellets and clumps of glasses and phlogopites. The silt-sized particles show ablated and striated surfaces, flow deformation of devitrified glasses, and layered onion-like structures. Iron-rich lamellae with meshwork crystal patterns occur among decrepitated crystalline mineral phases. This material is tentatively attributed to some vigorous ejection of deep Earth layers, or speculatively, to some previously undescribed olivine-phyric to basaltic and $\mathrm{Ni}$-, Cr-depleted siderolite material of meteoritic origin. - Key words: mineral dust, platform reef, sedimentation of particulates, sedimentary rhythms, stromatactis, climate conditions, magnetic susceptibility, gamma-ray spectrometry, geochemistry, mid-punctata Zone perturbations, Alamo impact event, Upper Devonian, Brunovistulian terrane, Moravia, Czech Republic.

Hladil, J., Koptíková, L., Galle, A., Sedláček, V., Pruner, P., Schnabl, P., Langrová, A., Bábek, O., FRÁNA, J., HLAdÍKOVÁ, J., OTAVA, J. \& GERŠL, M. 2009. Early Middle Frasnian platform reef strata in the Moravian Karst interpreted as recording the atmospheric dust changes: the key to understanding perturbations in the punctata conodont zone. Bulletin of Geosciences 84(1), 75-106 (9 figures). Czech Geological Survey, Prague. ISSN 1214-1119. Manuscript received November 24, 2008; accepted in revised form January 20, 2009; published online February 9 , 2009; issued March 31, 2009.

Jindřich Hladil (corresponding author), Institute of Geology AS CR, v.v.i., Rozvojová 269, CZ-165 00 Praha; hladil@gli.cas.cz.For the other authors'addresses see the Appendix. 
The study aims to develop a more comprehensive understanding of conditions during the early Middle Frasnian (E-MF) in the lower part of the Upper Devonian. The object of this work is to draw a more detailed picture of the connections between the structure and compositions of coeval off-shore platform reef strata and their capability to provide information about amounts and quality of the atmospheric dust which was deposited in off-shore marine areas, partly preserved and embedded in pure bio-organochemo-precipitated calcite limestone. This led to the devising of a complex of methods which progressively merge the elements of information: using biostratigraphy, mesoand microscale facies analysis, stratigraphic variation of magnetic susceptibility (MS), gamma-ray spectrometry logging (GRS), geochemical data sets, measured mainly by means of instrumental neutron activation analysis (INAA), and finally separation of larger and diagenetically less altered particles in the micrometre- and above micrometre size ranges.

The particular problems related to the E-MF time interval have been addressed as the number of open questions about sedimentology, background conditions and nature of the observed environmental perturbations is significant and increases over time. In the most general terms, the E-MF interval represents an acme in shallow water reef development with extensive flooding over continents and diversified reef morphologies (Boulvain \& Wood 2007, also Burchette 1981; Hladil 1986, 1988; Kiessling et al. 1999; Copper 2002). However, in contrast to this paleogeographical-facies image, the carbonate production seems to be reduced, and sedimentary and geochemical records are affected by perturbations of complicated structure (Geršl \& Hladil 2004, Buggisch et al. 2006, da Silva \& Boulvain 2006, Yans et al. 2007, Racki et al. 2008, Nawrocki et al. 2008, Ma et al. 2008, John et al. 2008). These papers started to map a time and space image of paleontological, but mainly lithological, geophysical and geochemical proxies to climatic forcing. The results describe significant secular trends with a real mosaic of environmental changes rather than sharply outlined and singular events, such as the Alamo impact in Nevada (Morrow et al. 2005, 2007; Pinto \& Warme 2008; or Warme \& Sandberg 1995, 1996; Morrow \& Sandberg 2003) which is of mid-punctata age and, thus, coeval with culmination, but not with the beginning the oceanic anoxic-dysoxic perturbations.

To answer this contradiction, there remains a need for work on separation of typically terrestrial and cosmic influences, secondary feedback mechanisms, as well as giving details about disturbations in climatic cyclicity and rhythms. The Moravian Karst area, SE Bohemian Massif, has been selected as an appropriate site where very pure limestone, vertically accreted on isolated platform reefs, should be a sensitive recorder of deposition of atmospheric and cosmogenic dust. The main advantage is that there were very shallow sedimentary surfaces which were distant from riverine or coastal detrital inputs but were effectively trapping the atmospheric background sediment (Hladil 2002, Bosák et al. 2002, Geršl \& Hladil 2004, Hladil et al. 2006a).

\section{Previous work}

Environmental disturbances of Lower to Middle Frasnian Earth systems became subject to increased scrutiny in the search for distal effects of the Alamo impact (Morrow et al. 2003). According to the most recent studies and compilations (Morrow et al. 2007, Pinto \& Warme 2008), a cometary impact occurred in an off-platform setting, on the edge of the Protopacific ocean, in what is now western Nevada, USA. The impact was approximately dated to the midpunctata Zone stratigraphic level.

The impact significantly reshaped the adjacent continental slope, shelf, and coast over distances of several hundred kilometres. The crucial evidence of this impact is supplied by huge seismically driven detachments and collapses of upper crustal, mainly sedimentary rocks (on the periphery of the impact), rapid excavation of the deep stratigraphic basement, mega-tsunami and back flow sediments of great thicknesses, shocked quartz, glassy melt grains, large carbonate accretionary lapilli, ejecta bombs, and distal ejecta debris. The size of the impactor has been calculated very approximately and in different ways. For illustration, a tectonically obliterated crater in the ocean floor could be $1.5 \mathrm{~km}$ deep and $50 \mathrm{~km}$ wide, $\pm 30 \%$, relevant size of the impactor for a comet with embedded stony bodies could be about $2 \mathrm{~km}$ in diameter, and height of primary tsunami waves are estimated to have reached $0.3 \mathrm{~km}$ (Warme \& Sandberg 1995). Around the target, the highest-magnitude seismic event in lithosphere and cataclysmatic dynamics in ocean and atmosphere led to a considerable disarrangement of sedimentary units that resulted in hiatuses, detachments, as well as redeposited and mingled materials.

In proximal areas, Morrow et al. (2003) found a strong $\delta^{13} \mathrm{C}$ oscillation dominated by a partial positive shift within the upper part of the C-unit of tsunamite sediments. The units A to D are marked upside down, so that this position is relatively deep in the redeposited materials. The authors inferred that this marker must have preceded the impact by 0.1 Ma. Subsequently, they initiated interregional correlation of isotopic data. This correlation was made in Belgium and Poland but Czech and Chinese published data where a disarranged mosaic of increased $\delta^{13} \mathrm{C}_{\text {carb }}$ values was found were also included (Yans et al. 2007). Locally, the $\delta^{13} \mathrm{C}$ positive shift started in late Early Frasnian, but remarkable assemblages of highly positive values (to $+5 \%$ ) were found in the Palmatolepis punctata conodont Zone 


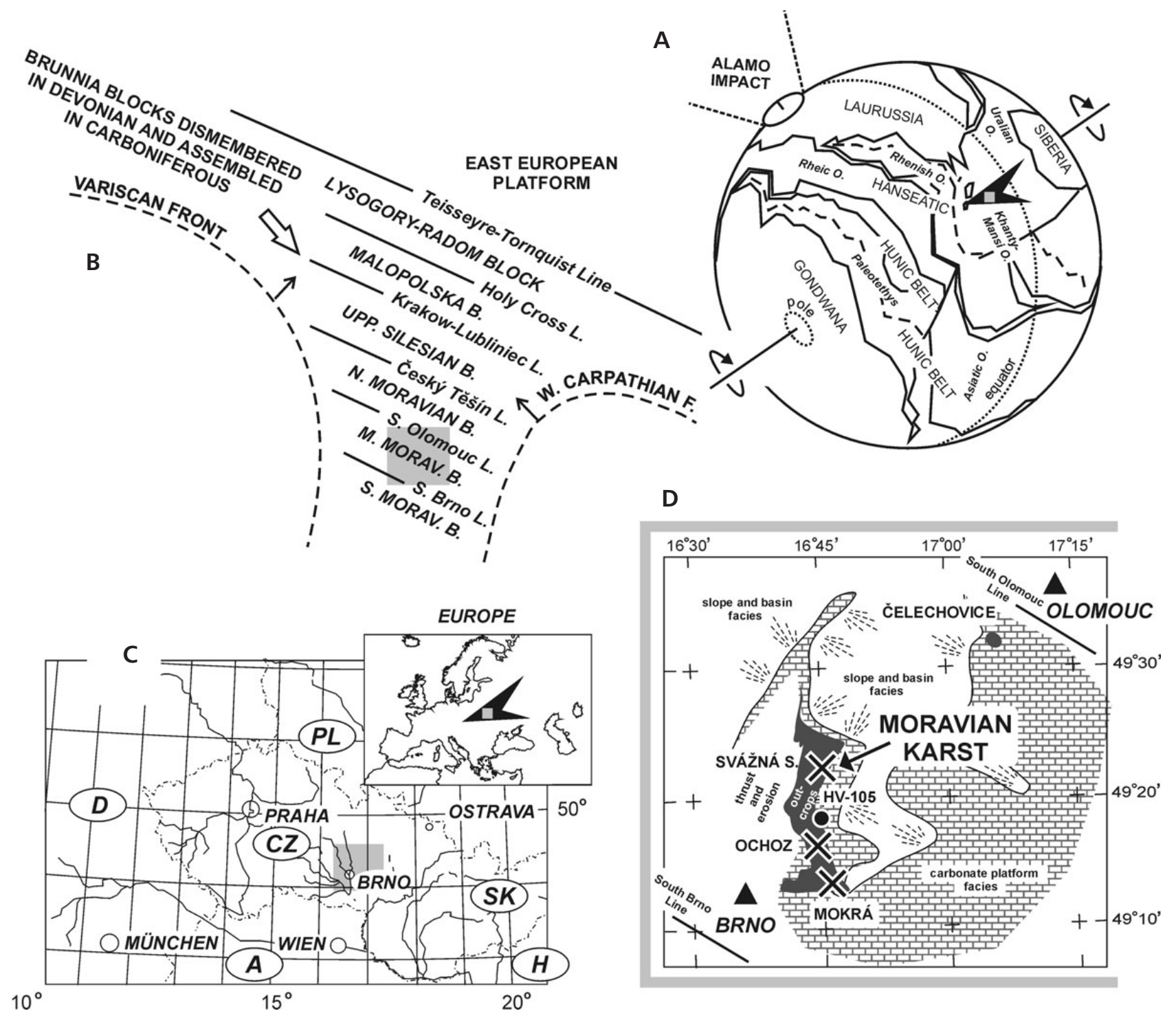

Figure 1. Location. $\bullet$ A - the early Late Devonian paleogeographical position of the Moravian Karst platforms and reefs relative to the Alamo impact on a simplified paleogeographic globe by Stampfli \& Borel (2004). $\bullet$ B - present-day upper crustal mosaic; the relicts of these former crustal blocks occur at the southern tip of subparallel juxtaposed units which form a wedge between the margins of deeply eroded Late Paleozoic Variscan orogen and younger, Mesozoic-Cenozoic Carpathian-Alpine thrust belts. $\bullet \mathrm{C}$ - geographically, the studied area lies in eastern part of the Czech Republic, historical country Moravia; the closest larger town is Brno. $\bullet$ D - localization of sections on a simplified geological map of the Moravian Karst outcrops together with continuation of limestone facies in subcrop of Carboniferous units.

(e.g., Geršl \& Hladil 2004, fore-reef facies of Moravian Karst). Two considerably broad bands with irregularly fluctuating high $\delta^{13} \mathrm{C}$ values, which decline in the endpunctata interval, are characteristic (Pisarzowska et al. 2006).

Although this positive $\delta^{13} \mathrm{C}$ anomaly is a stratigraphically broader fuzzy band, Yans et al. (2007) considered the main enhanced values as roughly coincidental to the Alamo event. Further more, considering that this Middle Frasnian isotope event has no visible relationships to major biota turnover or sea-level change, they hypothetized that it was triggered by the Alamo impact, which may have conse- quences in the massive dissociation of methane hydrates and rapid onset of a global warming episode.

Other results suggest that many ${ }^{13} \mathrm{C}$-isotope fluctuations, magnetic susceptibility (MS) shifts, or lithological/paleontological changes in the punctata interval cannot be so simply correlated with a single catastrophic change. It is particularly relevant to thick sections of mixed carbonate-siliciclastic sediments in Belgium (Boulvain \& Coen-Aubert 2006, da Silva \& Boulvain 2006, Boulvain 2007). Most recently, the buildups in Arche Member were chronostratigraphically moved higher up and assigned in full to the punctata Zone, and a new mound member has 
been defined in the upper punctata interval (La Boverie). The Belgian authors found significant eustatic control and several rapid eustatic fluctuations that indicate that the punctata event evolution is quite complex.

Slight or medium elevated Ir anomalies were found near the Alamo (Morrow et al. 2005, 2007), concentrated in terminal tsunamite layers, together with impact-generated carbonate accretionary lapilli, or laterally equivalent distal horizons. In distant areas on the globe, e.g., in the Moravian Karst, Ir concentrations of a few $\mu \mathrm{m} / \mathrm{kg}$ (ppb) are scattered in the sections rather than exclusively bound to the mid-punctata level (Hladil et al. 2004). A synthesis of all available information was given by Racki et al. (2008) who explained a broad early Middle Frasnian perturbation as an environmental effect of enhanced bioproduction anoxia related to high $\delta^{13} \mathrm{C}$ values in precipitated carbonate where the limiting strong oscillations are placed close below the base of the punctata interval and in its uppermost part. Secular trends towards slight cooling, land emergence, and intensified weathering have been inferred from increased $\delta^{18} \mathrm{O}$ and ${ }^{87} \mathrm{Sr} /{ }^{86} \mathrm{Sr}$ values. The MS data suggest two main pulses of increased detrital input: near the boundary of the $P a$. transitans - Pa. punctata zones and in the lowermost part of the $\mathrm{Pa}$. hassi conodont Zone (Hladil et al. 2006a, da Silva \& Boulvain 2006, Nawrocki et al. 2008, Racki et al. 2008). The correlative resolution of environmentally triggered events during the early Middle Frasnian perturbation remains very rough and approximate.

\section{Geological setting}

The Moravian Karst area, which was selected for this study, is located near Brno, Czech Republic (Fig. 1). Geologically, it is a series of Brunovistulian terrane segments which border the easternmost outer part of Variscan orogenic belts in Moravia. The terrane relates to the Brunnia paleocontinent (Zapletal 1931) and its predominant crystalline rocks, Brunovistulicum - the Brno unit, with similarities and extension to the upper reaches of the Wisła River (Havlena 1976, Dudek 1988). According to deep seismic sounding and gravimetry, this autonomous aggregate of Cadomian rocks widely extends the areas of outcrops and drilled localities and spreads far under the tectonically extruded and stretched Variscan and Western Carpathian Alpide arcs in the depths of several tens of kilometres.

The southernmost tip of the Brunovistulian Neoproterozoic basement, squeezed between these two orogenic fronts of different ages, consists of wreckage from numerous Neoproterozoic plutons, gneisses, biotite and hornblende schists, and other metamorphic rocks, together with a relict belt of Proterozoic ophiolite sequences.

The deeply dissected old crystalline rocks were locally covered by the Early Cambrian clastics which finalized the
Cadomian orogenic cycle with braided river delta and alluvial fan facies, combined with marine ingressions. The Middle Cambrian to Silurian (100 Ma interval) sediment cover is absent, and erosion prevailed until the Lower Devonian rifting and transcurrent faulting breakage (Cháb et al. 1984, Hladil 1988).

The Devonian continental sandstones and conglomerates with rare marine ingression levels are relatively thin, less than $50 \mathrm{~m}$ in average. The lithospheric blocks, stretched during continental extension, slowly subsided and were flooded by ocean water due to rising sea level. The southern Brunnia region in particular was covered by a pure limestone platform and reef sediments (Bosák et al. 2002, Hladil et al. 2006a). This extension was changed into transtension and then to transpression during the terminal Devonian and earliest Carboniferous. Strong orogenic deformation, however, did not develop earlier than with the end-Visean onset of the Late Variscan deformation.

The formerly separated parts of the Brunnia paleocontinent were again aggregated and tectonically rearranged within the margins of the Variscan orogenic belt. Collisional extrusion of former accretionary wedges and, subsequently, a huge Late Carboniferous shear zone propagated to both the Brunnia basement and its Paleozoic sedimentary cover; large volumes of allochthonous, mostly orogenic siliciclastic sedimentary units were thrusted over (Galle et al. 1995, Hladil et al. 1999, Bábek et al. 2006). The maximum stage of thermal alteration in Moravian Karst ranges between $150-250{ }^{\circ} \mathrm{C}$ (Franců et al. 2002).

The paleogeographic position of the southern Brunnia segments can be traced by paleomagnetic and paleobiogeographic links to Baltica for the Cambrian (Nawrocki et al. 2004), but other lithological and biogeographical rooting, based on the Neoproterozoic crystalline basement and its Devonian cover, points to a considerably distant eastern origin among peri-Gondwanan microcontinents (Hanžl \& Melichar 1997, Hladil 2002, Kalvoda et al. 2002). In this context, a separate early post-Cadomian position between Gondwana and Baltica was interpreted by several authors (e.g., Winchester et al. 2002, Hladil 2002).

The initial Cambrian position, therefore, can be estimated within broad error bands; tentatively - paleolatitudes $40^{\circ}\left( \pm 15^{\circ}\right) \mathrm{S}$ but at least $1500 \pm 500 \mathrm{~km}$ to the $\mathrm{E}$ from the early Middle Frasnian (E-MF) position. The E-MF paleomagnetic position for the Moravian Karst can be interpolated to $20^{\circ} \pm 10^{\circ} \mathrm{S}$. The path of drifting in a direction oblique to these paleolatitudes could be $2000 \pm 1000 \mathrm{~km}$ during $\sim 140 \mathrm{Ma}$ interval (?0.7 to $2.1 \mathrm{~cm} /$ year), but the transport in a collage of lithospheric plates remains unclear.

The main problems are rotation of Baltica (Cocks \& Torsvik 2005) and lack of good paleomagnetic data without strong post-Devonian overprints. The most significant 
evidence of the paleogeographical continuity is the end-Frasnian-Tournaisian bioprovincional integrity with terranes in SE Europe and Turkey (Hladil 2002; Kalvoda et al. 2003, 2008). The Frasnian facies and faunal dissimilarity between Moravian and Polish segments is strong (Zukalová 1980, Hladil 1994, Hladil et al. 1999, Hladil 2002), although a certain resemblance between the NW and SE flanks of the Upper Silesian coal (molasse) basin can be inferred from the presence of pure-limestone Eifelian-Visean carbonate platforms on both sides, but not further towards the shelf interiors (Narkiewicz 2007).

Even in the Variscan foreland, the lithologically discernible blocks are separated by faults and sutures. Various parts of outer carbonate platforms and inner Laurussian carbonate shelf were juxtaposed. The evidence exists that the individual blocks were transposed and former deep-water basins were closed, deformed, and locally obliterated (Racki 1993, Vierek 2007, Hladil 2002, Bábek et al. 2007). These sutures were often rejuvenated with younger faults in the Saxonian, NW-SE direction. In spite of this re-faulting, the location of three faults (Český Těšín - Ostrava, $\mathrm{S}$ of Olomouc, and S of Brno; Fig. 1) is undoubtedly coupled with sharp biofacies boundaries indicated by the compositions of coral and stromatoporoid faunas (Galle 1985, Galle et al. 1988).

The Lower-Middle Frasnian carbonate platforms and reefs in the Moravian Karst have numerous facies and faunal characteristics in common with other tropical shallow-water carbonate settings of Laurussia or worldwide. An increased similarity to Dinant and Kuznetsk faunas is characteristic for the Eifelian-Lower Frasnian interval. However, during the E-MF punctata interval, links to terranes on the European SE gradually become dominant and remain significant for all the late history of Moravian platforms. The Frasnian separation of individual platform reef segments developed concurrently, as it is evidenced by steepening of carbonate slopes, locally running to depths reaching about $1 \mathrm{~km}$ maximum (Hladil 1988, Bábek 1996, Bosák et al. 2002).

In addition, a constant E-MF supply of ocean water on large and shallow isolated or semi-isolated platforms is recorded by the absence of dolomite and evaporite pseudomorphs, and also adequate proliferation of reef-builders (Dvorák 1990, Hladil 1994). The E-MF interval in the Moravian Karst is characterized by a position just after the maximum stands of the Devonian sea level, and the pure limestones reflect a generally increasing delivery of eolian dust (Hladil et al. 2006a).

Three sections are compared in this paper; they represent different facies development (Fig. 1).

1. Mokrá Quarry West with deposition on very shallow gently inclined ramp.

2. Ochoz Skalka Quarry with deep lagoon in an atoll shaped reef structure.
3. Svážná studna Cave behind and around an exposed platform reef front.

The thicknesses of limestones related to the E-MF punctata interval (Hladil 2002, Hladil et al. 2006a) do not exceed 10, 15 and $30 \mathrm{~m}$, respectively. These relatively low thicknesses may correspond to a reduced E-MF carbonate production that was recently postulated in several papers (e.g., Boulvain \& Wood 2007, Racki et al. 2008). A possible reason is the sea water dysoxy reaching shallow bathymetric levels.

This deficiency was, however, followed by increased differentiation of platform reef relief. The light grey colored biohermal limestones remained locally in contact with sea level, with sufficient accretion of reef sediment, and they formed spots and stripes of reduced surface. The rate of sedimentation in lagoons and moats strongly decreased, and these became therefore deeper than before. Distinctively, there is slight or no relative enrichment of blackish grey lagoonal limestones by illite-smectite background sedimentary components relative to the light grey, shallowest limestone strata.

\section{Methodology and data sets}

The study design was robust but simple. After the reef-architectural and biostratigraphical positioning within the stratal successions was determined, the magnetic susceptibility (MS) logs were used for detection and correlation of anomalous intervals. Using the gamma-ray spectrometric methods (GRS) and multi-element geochemistry that consisted of whole-rock instrumental neutron activation analysis (INAA), the nature of principal log patterns was assessed. Then the large-volume samples from correlatable anomalous levels were taken to separate the nm- $\mu \mathrm{m}$ sized particles which could be carriers of specific rock properties. These were analyzed by means of standard electron microprobe techniques (EMP, EDX, SEM). Using this biostratigraphy-MS-GRS-INAA-mineralogy procedure we were able to refine the previous data for the E-MF (Hladil et al. 2006a).

Biostratigraphy and facies. - The Pa. punctata conodont zone correlative set of beds was derived from the 1960-1980's geological survey base data on conodonts from peri-reef sediments (Palmatolepis punctata with Mesotaxis asymmetrica and Ancyrodella gigas above; former Middle asymmetricus Zone). The punctata interval has also been projected to the scale of the local stromatoporoid-coral biostratigraphy (Hladil 2002; Hladil et al. 1999, 2006a).

It was found that the base of punctata Z. coincides with the following faunal replacements: Rugosa - Hexagonaria and Thamnophyllum monozonatum by Alaiophyllum and 


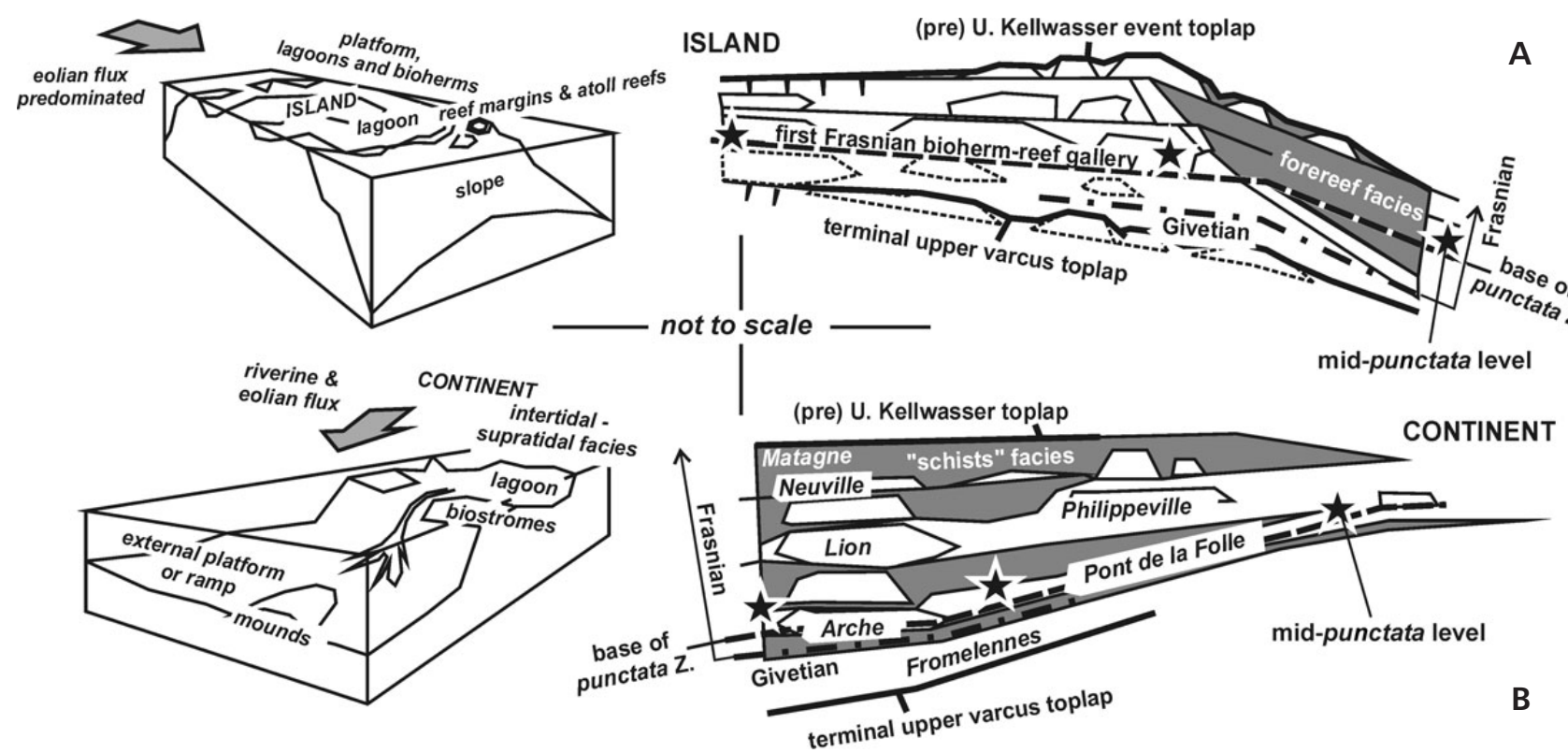

Figure 2. Illustrative and approximate ideal outlines of facies architecture. The stratigraphic position of the base-punctata and mid-punctata levels is marked. • A - the Moravian Karst facies, isolated platform reefs, simplified after Hladil $(1983,2002)$. B - Belgian mixed carbonate-siliciclastic facies, mostly ramps with reefs, simplified after Boulvain (2007). In both the systems, the punctata interval corresponds to the $1^{\text {st }}$ Frasnian gallery of laterally intermittent bioherms and other bioaccumulations.

Tabulophyllum spp; Tabulata - Alveolites suborbicularis and Crassialveolites evidens by Alveolites complanatus group; Stromatoporoidea - Actinostroma dehorneae by Amphipora moravica and Syringostroma vessiculosum. Amphipora rudis repopulated sheltered areas in the upper third of the punctata Z., and the first detectable occurrences of Multiseptida and Paratikhinella or very similar foraminifers can be traced in limestone thin sections to the depth of the laterally correlated punctata/hassi level (Galle et al. 1988, in terms of present-day local stratigraphic practice).

Lithostratigraphically, the base of the $1^{\text {st }}$ Frasnian reef gallery of cross-facies correlation value has a substantial applicability for approximate determination of the E-MF base ( $c f$. Dvořák \& Friáková 1978; Galle et al. 1988; Hladil 1983, 1988, 1994, 2002; Hladil et al. 1999, 2006a; Bábek et al. 2007) (Fig. 2). New thin sections from the Mokrá and Ochoz sections were employed in expanding the databases on biostratigraphy and microfacies. The vertical spacing of thin sectioned intervals was $\sim 0.5 \mathrm{~m}$, using always the $3-10$ thin-section arrays for covering the variability of rocks ( 320 sections, $1 / 4$ for microprobe).

Magnetic susceptibility (MS). - The MS stratigraphy served as a primary information resource and was primarily used for high resolution juxtaposition of the sections. The relevant methods, techniques and their application in limestones have recently been described in detail (Crick et al. 1997, Ellwood et al. 2000, Hladil et al. 2006a, DaSilva \& Boulvain 2006).
Specifics: The sampling was carried out on successively added parallel sections side-by-side, with 10-20 cm spacing of samples, and the values related to levels with variable lithologies were strengthened by horizontal rows of samples. Raw datasets are called grids. The MS measurements were carried out in the Průhonice Paleomagnetic Laboratory using the Agico kappabridges KLY-3/4.

Interpretation skills: For this case of pure limestone, the interpretations followed the principles that the MS stratigraphic variation in pure limestones is less related to locally occurring stratal arrangements and cycles than it was assumed for limestones in general (Whalen et al. 2000, Whalen \& Day 2005, da Silva \& Boulvain 2006). The record reflects the overall climatic control of quantity and quality of the delivered atmospheric dust (Hladil et al. 2006, da Silva et al. 2008, Boulvain et al. 2008a). Certainly, the major eustatic cycle control on dust and overall detrital production and dispersal exists, but the final result is far more complicated by nuances of climates, atmospheric/ocean circulation and facies (Hladil et al. 2006).

Using a very simplified scheme of the relationships between global sea level fluctuation and magnitude of detrital delivery and paramagnetic components of complex impurity in limestone, we can state that there were repeatedly documented situations when long term highstand settings and low MS correspond to decreased delivery of this impurity whereas the low stand settings with large emerged areas of land correspond to high production and dispersal leading to high MS (Ellwood et al. 2000, Hladil 2002). This grand scheme is often valid for analyzing the se- 
quences of limestones. However, a just inverse function has recently been defined for major environmental perturbances (crises) in the Devonian where low sea level, low MS, but also low detritism and low delivery of dust are connected, and vice-versa, high sea level, high MS, high delivery of highly magnetic compounds was recorded.

It was suggested that these anomalous situations might have arisen due to anomalous, extremely calm and stormy atmospheric/ocean conditions (Hladil et al. 2002, 2008b). A relevant modus operandi for these inverse settings can be suggested based on solid evidence of powerful interregional correlation using the MS stratigraphic variation which is exclusively, or at least mostly, realizable due to continents and basins crossing eolian dust input.

These data relate to two published cases: the almost cosmopolitan similarity of the Kačák event MS curves (Crick et al. 1997, Hladil et al. 2002) and very good matching between two long, Eifelian-Frasnian composed MS sections in Moravia and Belgium (Hladil et al. 2006a, Boulvain et al. 2008a). In spite of the difference which exists between these distant basins, where, for example, the Belgian basins have significant riverine and coastal detrital inputs, the evolution of MS stratigraphical patterns is almost identically developed in this and other basins compared with the Moravian pure-limestone platform reefs.

Gamma-ray spectrometry (GRS) and instrumental neutron activation analysis (INAA). - The gamma rays registered in surveys of rock formations are based on isotopes ${ }^{214} \mathrm{Bi}$ (from U decay chain), ${ }^{208} \mathrm{Tl}(\mathrm{Th})$ and ${ }^{40} \mathrm{~K}(\mathrm{~K})$, the total gamma-emission is registered in selected energy windows. The latter often differs according to equipment used and has, therefore, only relative or informative value. Although the first portable multi-channel gamma-ray spectrometers were designed for field applications in the 1960's (Moxham et al. 1965, Knoll 1989, Darnley 1991), the GRS outcrop logging method for detailed stratigraphic work and paleoenvironmental purposes in limestones came into use much later (e.g., Reisinger \& Hubmann 1998, Ruffel \& Worden 2000, Hladil 2002).

For this study, a calibrated gamma-ray spectrometer GS-512 Geofyzika/Satisgeo $(7.62 \times 7.62 \mathrm{~cm}=3 \times 3$ inch $\mathrm{NaI} / \mathrm{Tl}$ detector) was used in a mode with direct display of computed concentrations of $\mathrm{K}(\%), \mathrm{U}$ (ppm) and Th (ppm). Conditions for measurement involve keeping the probe axis bedding-parallel and perpendicular to smooth and planar parts of the wall (as much as possible), and sufficient stabilisation during a 240 s period.

One advantage of this GRS application is that we can obtain \pm averaged values where $\sim 95 \%$ of the signal comes from a target which is equivalent to $90 \mathrm{~kg}$ large-volume samples, and optimum low overlap distances of target centres are $0.5 \mathrm{~m}$. This spacing was used for reef limestones in this study, which are thought to have encompassed all the
GR-hot spots, fills, lenses, or sutures, which commonly escape point sampling.

The $1 \mathrm{~kg}$ point samples for instrumental neutron activation analysis (INAA) measurements for geochemistry were taken with the same spacing of $0.5 \mathrm{~m}$. They involved particularly the packstone/grainstone matrix. The rocks were ground to pass through a $0.07 \mathrm{~mm}$ (200 mesh) screen prior to homogenization, and $150 \mathrm{mg}$ portions were analyzed by means of short and long-term irradiation activation analysis. The method from the 1930's came to use in the 1960's, when principles were compiled and applications performed (e.g. Bate et al. 1959, Leipunskaya et al. 1960, Eckhoff et al. 1968). The technical data related to the subsequent and most recent INAA technology development at the Nuclear Physics Institute are described in a series of papers (e.g., Kuncír et al. 1970, К̌anda \& Kreisinger 1983, Randa et al. 2007). The use of INAA in limestones does not significantly differ from other studies of geomaterials in general, only the dominant $\mathrm{Ca}$ emitter after irradiation $\left({ }^{49} \mathrm{Ca} \rightarrow{ }^{49} \mathrm{Sc}+\gamma 3084.5 \mathrm{keV}\right)$ has an effect on measurement of trace elements. Further, the computing of Ce, Mo, $\mathrm{Nd}$ and $\mathrm{Zr}$ concentrations requires slight correction due to fission of uranium. As it is generally known, the best conditions for counting individual isotope (element) spectral data differ according to specific half-life radionuclide decay time and possible spectral interferences. Therefore, selective and repeated measurements at appropriate time intervals after the irradiation provided high precision results. These measurements were also calibrated by means of comparison with ICP-MS measurements (Hladil et al. 2006a, Strnad et al. 2008).

Separation and assessment of rare non-carbonate particles. - Two $50 \mathrm{~kg}$ samples (Mokrá, Ochoz) were taken by means of vertical channel sampling through $1.5 \mathrm{~m}$ thick anomalous intervals. The sampling and processing procedure was repeated, for verification. The limestone was crushed first in a jaw crusher and then in a rolling mill, using gradual adjustment of distances and movement of jaws and cylinders, respectively.

Optimizing the conditions: Co-located forerunner samples were used for adjustment of material disconnection parameters, and particulate pollutants were sampled and analyzed at machines, in the room and outdoor space to avoid unexpected sources of contamination. The material was repeatedly sorted on Wilfley tables, wet gravity based separation shaking devices, and four heavy size fractions were treated separately using gravity and ultrasonic techniques. Dried and cleaned material was sorted using a magnetic separator at 2.0 A. The magnetically separated fractions were finally sedimented in bromoform $\left(\mathrm{CHBr}_{3}\right)$ at real $\rho 2.852$ and then diiodomethane $\left(\mathrm{CH}_{2} \mathrm{I}_{2}\right)$ at $\rho 3.303$.

From the resulting heavy fractions (according to size, magnetic properties and density) there is a reasonable 
chance of subsequently locating the best yields of suspect grains/particles. The final gain of suspect grains was sorted and documented first according to morphology and semiquantitative composition of grains (standard SEM and EDX Jeol), and after mounting and polishing, determination of individual phases was made using a Cameca SX-100 microprobe. The work was carried out in the Laboratory of Physical Methods of the Institute of Geology AS CR.

\section{Results}

Faunal and thanatocoenotic successions. - The description of environmental mosaics and how environmental changes can differently impact on benthic carbonate factories do not require use of very distant sections. The mingling of two hypothetical end-members corresponding to a clear record of major environmental forcing, micro-events, and events of supra-regional dimension, and complicated 3D patchy mosaic structure can be illustrated using sections which are only few tens of kilometres apart (Mokrá, Ochoz and Svážná studna - Figs 1, 3-6).

Mokrá (Hladil 2002, and literature cited therein). The early Middle Frasnian (E-MF) punctata correlatable interval spans from the mark $-58.0 \mathrm{~m}$ (base) to $-47.7 \mathrm{~m}$ (upper end; measured from the above-lying Frasnian-Famennian (F/F) disconformity). The E-MF shallow ramp biofacies are characterized by remarkably low abundances of corals. Beginning from the base of the E-MF, the uppermost field record of a ?Hexagonaria colony fragment is $4.5 \mathrm{~m}$ below this base; one fragment of ?Phillipsastraea was closer, only $1.3 \mathrm{~m}$. Rare coral pieces comparable with Peneckiella, Thamnophyllum monozonatum, ?Disphyllum cf. karolinae were recorded 4.2-3.7 m below the E-MF, with continuation in small ?Thamnophyllum fragments stretching up to the basal laminites - the latter is particularly common on or closely underlying a dark-grey to blackish storm bed, where 5-15 mm fragments of Alveolites suborbicularis were also found. The singular colonies of Crassialveolites evidens and Tyrganolites cf. frasnianus under the E-MF were found only due to several hundreds of meters of relevant rock core (quarry-exploration drilling network).

Above the E-MF base, the type populations of the stromatoporoid Actinostroma dehorneae were suppressed in abundance, although other Plectostroma-Actinostroma-related forms recolonized this ramp at several levels above. The same decrease in abundance, but with diversification of morphotypes, was found for Scoliopora denticulata.

The E-MF beds are also marked by scattered occurrences of Alaiophyllum and Tabulophyllum rugose corals, together with Alveolites ex gr. complanatus. Gradual but massive colonization by Amphipora moravica and Amph. tschussovensis, with other SE Laurussian-Gondwanan amphiporids succeeding closely thereafter, is the most visible sign of changes in this interval. However, the species Amph. rudis survived this invasion and competitively repopulated the ramp again, mainly in the upper third of the E-MF.

Thus, in the conditions found in Mokrá, the first occurrence of Amph. moravica considerably preceded the first arrival episodes of uniserial Multiseptida and Paratikhinella foraminifers, which mark the end of the E-MF and the base of the above-lying hassi-Z. interval. The stratigraphic concurrency of the Amph. moravica, and Atelodictyon, Syringostroma vessiculosum fauna and conodonts of the punctata $\mathrm{Z}$. (formerly middle asymmetricus Z.) was inferred from drilling sections from surrounding areas in general (Galle 1985, Galle et al. 1988, Hladil 2002, Hladil et al. 2006a).

Several other biofacies markers are worthy of note. At the base of the E-MF, remarkable "Moravamminidae", and ?Palaeoberesella felt-like structured algal mats occur, alternating with coral-free gastropod beds. The deepening above the E-MF base is marked by the presence of brachiopod, mollusc, crinoid, and rugose coral skeletal hash. In thick beds at $-56 \mathrm{~m}$, a diversified assemblage of stromatoporoids contain coenostea of ?Habrostroma, Stromatopora, Clathrocoilona and ?Idiostroma; the latter often with traces suggesting intense sponge bioerosion (Figs 4M, 6).

Figure 3. Mokrá and Ochoz sections. General views of recent quarry shapes, appearance of the beds in quarried walls, and the most remarkable facies in these sections. • A - outlines of Mokrá Quarry West (coordinates of the section correspond to tip of arrow). B - Mokrá, a photograph of quarried beds is compared with the scale which is used in diagrams in other figures. • C, D - Ochoz Skalka Quarry, outlines of the quarry and beds with scale. - E-G, H, I - remarkable facies from Mokrá and Ochoz, respectively. E - fine-scale, laminated coverstone fabric results of alternation of cryptalgal, "Moravamminidae" and bacterial mats with bioclastic/lithoclastic grainstones. F - abundant fenestral fabrics are preserved in thicker layers of poorly washed material of similar type. They are partly thrombolites, but many of them reflect only processes of sedimentation and earliest stages of diagenesis. Degassing of water in intertidal and related cementation were possibly employed, in combination with bubbles from decayed organic matter and secondary leaching and settling of the sediment. Collapsed dish-like sutures are in lower and upper parts of the figure; these may originate due to the escape of fluids during sedimentation. $\mathrm{G}$ - the laminated coverstone layer ends with a hardground (hgr) which is covered by broccoli-shaped stromatolites (stl). $\mathrm{H}$ - bulbous coenostea of stromatoporoids (stp) redeposited by storms; sponge borings of Entobia type (ent). I - the accreted and intermittently storm-amalgamated, poorly washed boundstones contain a number of amphiporids (amp), stachyodids (sta), a variety of bulbous stromatoporoids (stp) and branched rugose corals (rug). 
MOKRÁ, QUARRY WEST

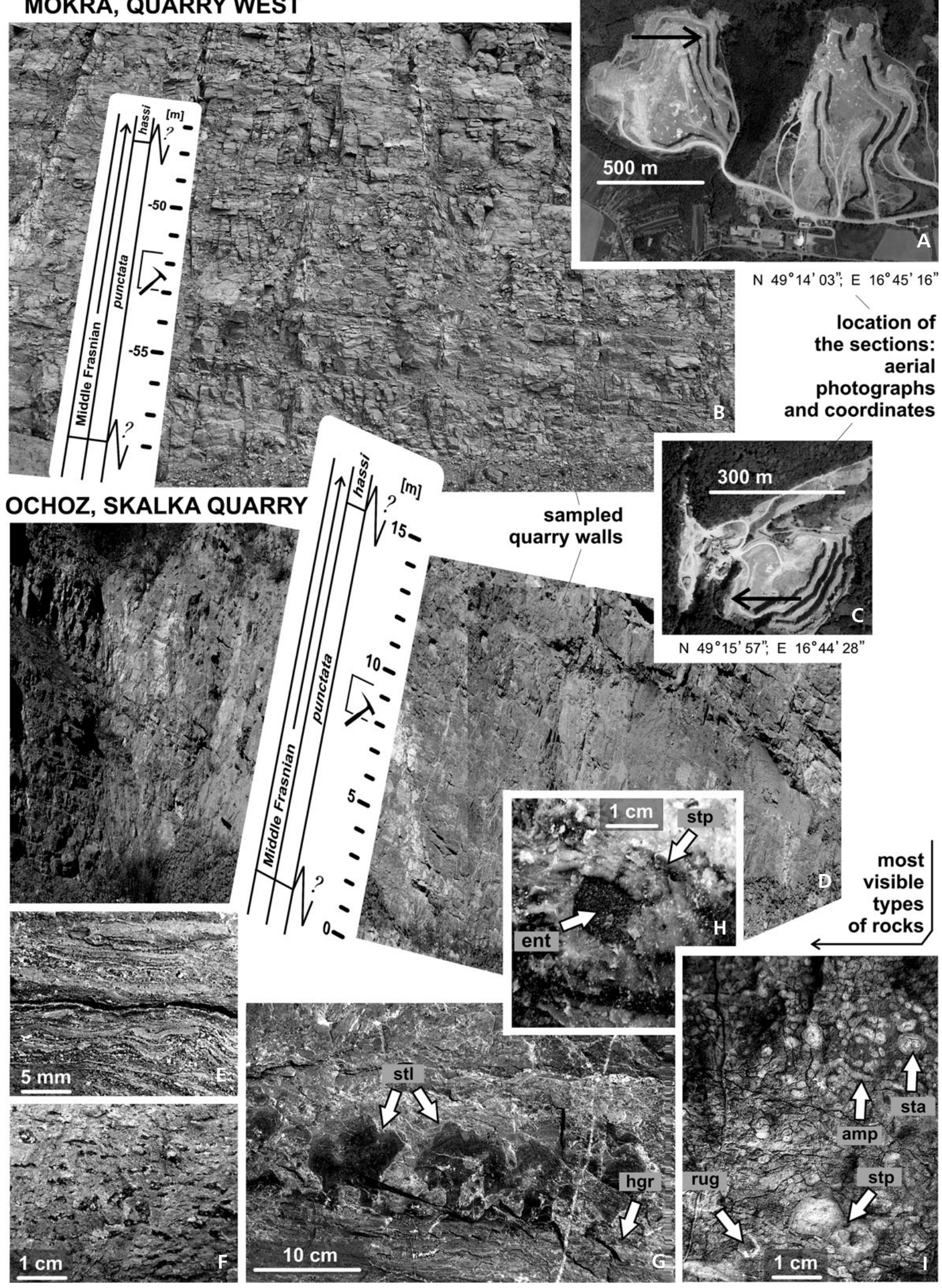


Ostracod valves are common. Abundant calcispheres with Parathurammina and Irregularina foraminifers characterize the overlying rhythms where relict populations resembling the taxa Amph. pinguis, Amph. laxeperforata, and Amph. rudis were gradually replaced by eastern-type amphiporid immigrants and the first Amph. moravica. At the mark $-53.5 \mathrm{~m}$, Atelodictyon moravicum, Parallelostroma and ?Stromatoporella spread over several surfaces and have a high population density. These levels are well recognizable in the architecture of stratal units (Fig. 6).

Above, a series of microbial mats interlacing the skeletal/lithoclastic grainstones developed, with an abrupt upward transition to (fresh) skeletal grainstones with unaltered bioclasts and clear cements. The limestone prevailing at the $-52 \mathrm{~m}$ mark consists of laminites and contains originally semi-lithified lumps, but amphiporids are very rare.

The anomalous appearance of this part is accented by a specific insertion which corresponds to the microsequence at the mark of $-51.5 \mathrm{~m}$. Here, the stromatoporoids Plectostroma-Actinostroma and Stachyodes are mixed together with many other incompatible shallow-water lithoclasts. Coenostea of redeposited stromatoporoids are often opened by sponge borings, Entobia. Sparse fauna in the overlying beds is dominated by diverse amphiporids and many unilocular benthic foraminifers.

The next truly remarkable point in this section relates to a short series of bedding contacts which developed at the $-48.5 \mathrm{~m}$ mark (= from the bottom to top: an episodic sponge-spicule wackestone facies/hardened packstones/ bioeroded hardground/horizon of broccoli-shaped stromatolites - Figs 3G, 4C, D).

Close under the upper E-MF boundary, a couple of biofacies characteristics emerge in a considerably irregular, intertidal/subtidal set of beds. These are, firstly, the co-occurrence of Amph. tschussovensis and nodules of Solenoporaceae (red algae), and secondly, grainstones with 10-15 cm Megalodont shells (bivalves). These two specifics are typical mainly for the overlying hassi to rhenana Zs. at Mokrá (compare the Moravian stratigraphic literature cited; also Figs 4, 6).

Ochoz (Geršl \& Hladil 2004, and literature cited therein). In this section, the E-MF was adjusted between the marks 0.6 (base) and $15.1 \mathrm{~m}$ (upper end), i.e. in beds above the pre-selected reference point (op. cit.) - Figs 3, 5 , and 6. None of the distinctive regional biostratigraphic markers are absent in this section. In spite of this relative completeness of the biostratigraphic evidence, the Ochoz section belongs to a depositional system with many specific features and problems. These relate to its deposition in about $10-30 \mathrm{~m}$ of water and a $2-3 \mathrm{~km}$ wide atoll-shaped lagoon which was rimmed by narrow reef margins with stachyodids and crinoids.

This lagoon was filled by very pure but blackish grey limestone (CGS geological map sheet 24-413, 1 : 25.000).
In Skalka Quarry, the Givetian-Frasnian (G-F) boundary beds, heavily populated by Amphipora angusta for the last time, were reached by quarrying in October 2008. The successions below are characterized by alternation of light and dark beds (Fromelennes-like interval), whereas the overlying punctata to transitans beds are predominantly blackish grey, well bedded limestone containing sporadic amphiporid and stromatoporoid, brachiopod, tabulate and rugose coral faunas; Thamnopora boloniensis are conspicuous by their whitish branched coralla in several levels.

The stromatoporoid community close below the E-MF base is already richer than its local precursors and is dominated by Actinostroma hebbornense - devonense - crassepillatum - dehorneae and Amphipora pervesiculata - laxeperforata - rudis. Close above the E-MF base $(27 \pm 2 \mathrm{~m}$ above G-F), Atelodictyon cf. sphaericum spissum, Synthetostroma actinostromoides, ?Taleastroma, Stromatopora, Hermatostroma longipillatum, and Stachyodes lagowiensis occur together with Amph. rudis. At Ochoz, the populations of Act. dehorneae and Amph. rudis were less environmentally deprived than elsewhere in the Moravian Karst.

In the background of the newly arriving E-MF forms such as Amph. moravica, Syringostroma vessiculosum, diverse Atelodictyon and Tienodictyon species, many archetypal (conservative) lineages survived. These can be exemplified by admixtures of some Lower Frasnian-like amphiporids, and the same was found for Thamnophyllum and Disphyllum corals.

The basal E-MF sea level rise is marked by the occurrence of brachiopods, trilobites, sponges, ostracods and bryozoans. The layers containing these fossils are covered by Parathurammina packstones/grainstones where the amounts of shell-hash lenses and scattered crinoid ossicles and other echinoderm material are increasing stratigraphically upwards and interbedded limestone beds containing small spherical brachiopods occur. Then, beginning from peloidal-?pelletal limestones with gastropods, coarsening-upward branched-stromatoporoid accumulations developed, being interleaved by typical massive-stromatoporoid boundstone banks with overgrowths of Disphyllum, Thamnopora and Scoliopora corals - at 3.5 m (Figs 3, 5 and 6).

At the $4 \mathrm{~m}$ mark, laminites and hardened surfaces occur. In addition, thin beds with extremely impoverished faunal communities are particularly common at about one third of the E-MF. At the $5 \mathrm{~m}$ mark, these beds contain only larval stages of organisms. Higher in the section, horizons with ostracod, mollusc and trilobite shells alternate with the more uniform levels with calcispheres, Caligella foraminifers or gastropods.

The level around the $7 \mathrm{~m}$ mark is remarkably separated (Fig. 6) and consists of diversified stromatoporoids, with a predominance of thick-branched stachyodids. The presence 
of mottled sediments, bioturbation structures, holes and fillings marks the lower parts of the mid-E-MF strata at $8.5 \mathrm{~m}$ of the section. These marks are indicative of lowstand settings. In microscopic view, small clasts biodegraded to various degrees are dominant, although peloids-?pellets and green algae thalli occasionally prevail.

A sea level rise related to the upper half of the anomalous interval was marked by the presence of extremely well-preserved drowned (buried) amphiporid lawns in its earliest stage, but all this was subsequently covered by diverse scatters and accumulations of stromatoporoid branches and heads (at about $10.5 \mathrm{~m}$ ). The stromatoporoid scatters are interleaved by lithoclastic grainstones with many traces from microbially affected materials. Here, also microstromatactis structures were found. The highest number of sponge borings, Entobia, in stromatoporoid coenostea is typical just for the above-lying beds.

Beginning from a horizon with a scatter of caliche fragments, diverse taxa of stromatoporoids and corals particularly correspond to the local stratigraphic concept of stratigraphically new, undoubtedly E-MF compositions stromatoporoids Atelodictyon, Stromatopora, Stromatoporella, Tienodictyon, Syringostroma and corals Alaiophyllum, Tabulophyllum and Alveolites (?Alv. obtortus and Alv. ex gr. ?complanatus), with poor representations of actinostromids and conservative survivors; concurrently, Cribrosphaeroides and other large foraminiferal tests are abundant. The small uniserial foraminifers enter the section at the upper E-MF boundary, $0.2 \mathrm{~m}$ below and $0.4 \mathrm{~m}$ above the designated ?punctata-hassi correlative surface.

Svážná studna (Otava \& Kahle 2003, Dvořák et al. 2005). The $30 \mathrm{~m}$ thick E-MF section (between -41 and $-11 \mathrm{~m}$; Fig. 6) exemplifies the reef margin facies with front-toback fluctuation and/or position shifted slightly back to the flat or moat. The smoothly eroded and wet parts of cave walls that look as if polished provide nice examples of the stromatoporoid-coral faunulae.

In this cave section, we had to rely more on the information given by section imaging than sampling and thinsectioning, because the cave is protected by law and sampling is restricted. A favourable condition is that these faunulae have counterparts in several short E-MF sections in neighbouring karst landscape (clints, rillen karren, and historical limestone pits), from which the comparable fauna was thinsectioned and catalogued among the stock specimens.

A significant impoverishment of faunas including Thamnophyllum and Alveolites suborbicularis was observed at the E-MF base, and the Hexagonaria rugose corals seem to disappear even before $5 \mathrm{~m}$ under the base. This base is marked by the occurrence of brachiopods, crinoids, and fragmented massive stromatoporoids. Gastropods and pelletal accumulations mark an episodic shallowing at $-40 \mathrm{~m}$ (Fig. 6). A remarkable sequence of thick sediments with stromatoporoids is markedly developed between the -38 and -34 marks, where the initial prevalence of stachyodids is replaced by diversified stromatoporoid faunas with numerous fragmented large branches and heads, Hermatostroma and Stromatopora being the most abundant genera. Rare fragments of branched rugose corals are comparable with Disphyllum, Temnophyllum, Alaiophyllum, and ?Diffusolasma.

Higher in the section, the algal coated skeletal detritus alternates with bioclastic grainstones and contrasting beds with stachyodids where St. lagowiensis gradually predominates over St. paralleloporoides and St. ?costulata forms. The fauna resembles the upper parts of the Polish Macgeea-Thamnophyllum coral zone with the Hexagonaria aff. hexagona biohorizon at its bottom (Wrzolek 1992). Fine bacterial lamination and fissured/bioeroded surfaces occur below the sharp change to the anomalous beds in the section. This overlying succession of beds consists, sequentially upward, of lenses containing lithoclastic/algal-crust debris, fining upward scatters in beds and a transition from the amalgamated to well bedded material where the variety of faunal and algal remains are indicative of a wide cross-facies source from reef aprons, carbonate sandbanks and rocky cays that include fresh bioclasts to repeatedly microbially altered and abraded grains and fine particles.

Locally stromatactis fabrics developed $(-21.7 \mathrm{~m}$; Fig. 6). The stromatactis limestone lies directly on truncated rocks. The surface of this limestone was again truncated and covered by a scatter of debris (Hladil et al. 2006b). Crinoidal debris deposited in thin lenses or spray was delivered by storm flooding from the outer areas, locally from the E. Above these anomalous beds, the upper part of the E-MF consists of thin grainstone layers and algal bindstones. These parts of the section are interleaved by several biohorizons with Alv. obtortus and/or Alv. complanatus tabulate corals, together with those which are marked by broken, $2-2.5 \mathrm{~cm}$ in diameter, cylindrical branches of phillipsastraeid rugose corals. These corals have numerous thin septa and wide dissepimentarium at the walls, and they can preliminarily be compared with Sinodisphyllum, similar to Belgian late E-MF (Boulvain \& Coen-Aubert 2006).

Close above the end-E-MF hardground surfaces, many stromatoporoids, corals and brachiopods reappeared, crinoid debris is present, and foraminiferal fauna became more abundant and diversified, including uniserial calcareous forms. The sponge borings, Entobia, marks two levels: above the mid-punctata anomalous beds and close above the punctata-hassi boundary. Entobia are, however, absent at the E-MF base (Fig. 6).

Rock composition and fabrics. - These Moravian E-MF limestones are very pure, the calculated mean contents of 
non-carbonate impurities for Mokrá and Ochoz are 84 and $53 \mathrm{~g} / \mathrm{kg}$, respectively, from large volume dm-m-scale samples. Less accurate data exist regarding Svážná studna, 40-50 g/kg (limited sampling; technically limited field GRS in caves, effects of Rd, Ra). Lower values of impurities, 27, 13 and $9 \mathrm{~g} / \mathrm{kg}$, respectively, were inferred from small volume $\mathrm{cm}$-dm samples.

The basic reason why this difference is so large is that the point samples have a selective character, getting a purer part of the rocks out. On the other hand, the large volume samples show the embedded impurity much more completely, encompassing all variously localized stylolites and disseminated occurrences of thin discontinuous lamellae and pocket fills. These impurity-rich objects have been identified as relicts from exceptional dust deposition episodes in shallow subtidal/intertidal platform reef conditions. Others corresponds to complex reworked reef rocks with increased impurity concentrations of this origin. The high-to-low-value ratio correspond, most likely, to the degree of water agitation, being increased from sheltered ramp, atoll lagoon to platform reef margin as 3, 4 and 5, respectively. Therefore, the details of related depositional systems must differ considerably for the sections from Mokrá, Ochoz and Svážná studna.

The shallowest facies of the Mokrá E-MF section contain stromatolites and beach-rocks, and the deepest ones are marked by Amphipora packstones. Within this range a number of types of foramol-like facies occur, typically with the presence of micritized grains and algal or bacterial mats. A relatively low content of large metazoan reef builders is characteristic, and the stromatoporoid-coral levels with $10-30 \mathrm{~cm}$ heads represent less than $5 \%$ of total rock volume. The slightly inclined surface of this large and shallow ramp was relatively smooth; erosional remnants of dunes, bars, or channels are very rare. In general, the facies with lithological signs of intertidal conditions amount to about $35 \%$ of the total rock volume (Figs 3, 4 and 6).

The lagoonal sediments of the Ochoz section represent a different depositional system. Here, rare occurrences of caliche fragments and scatter of subaerially altered bioclasts mark the shallowest sources and, indirectly, also the shallowest settings on this reef. In the opposite system, the blackish Amphipora-rugose coral packstones with trilobite shells mark the deepening episodes. Between these two extremes a number of foraminiferal sand, packstone, and floatstone varieties occur. Predominance of amphiporid/stachyodid floatstones/boundstones (rarely also bafflestones) can be rated as very typical (Figs 3, 5 and 6). The facies with undoubted intertidal signs are minor constituents in the E-MF range of beds, accounting for less than $15 \%$ of the total rock volume (Fig. 6).

At Svážná studna, the facies variation ranges from laminar algal coatings and reef rubble bind by secondary

Figure 4. Mokrá; selected thin sections. - A - incompletely preserved microstromatactis-like structures (mst) are characterized by relicts of early geopetal sediment on the cavity floor and jagged roof, where some grains fell down. Grainstone consists of irregularly shaped bioclasts and rugged biomorphs of several sizes. Detail: Grains are micritized to different degrees; spheres and Parathurammina-like test are common. $\bullet$ B - complicated, dissolved margin of a large bivalve specimen (bvl), possibly Megalodont. The most common allochems are foraminiferal, algal and larval biomorphs of various shapes and sizes. Small grains and lumps are micritized. $\bullet \mathrm{C}$ - densely packed structure of (micro)packstone/wackestone with recrystallized bedding sutures, patches and canals. Some of them are filled by vadose silt. Detail: The parts which are better preserved contain numerous calcified sponge spicules. $\bullet$ D - a hardground occurring under the carpets of broccoli-shaped stromatolites; the cementation usually prevails over the recrystallization. The hardground is typically opened by $1.5 \mathrm{~cm}$ wide and several cm long cylindrical borings (bor; left). They were filled by several layers of shallow-water calcisiltite and cements. Inside the hole, the recrystallized crusts alternate with graded microsequences (upper right). The obtuse end of the hole is rimmed by large rhombohedra of former Fe-calcite and dolomite compositions (lower right). $\bullet$ E - extremely irregularly shaped branches of amphiporids show a tendency to coating of the substrate or overgrowing of their own fragments. Redeposited fragments have corrosion-widened axial canals and hardened micritic envelopes (upper right). Detail: First uniserial foraminifers occur in fine-grained rock matrix (upper left). $\bullet \mathrm{F}-$ also fragments of strictly cylindrical amphiporid stems bear relicts of micritized envelopes. The fine grainstone varieties consist of mixed populations of micritized and fresh bioclasts. - G - coarsely fenestral clotted sediment with locally embedded fragments of calcretes/caliches (clc). Geopetal fills of fenestrae are fine-crystalline rather than particulate. $\bullet \mathrm{H}$ - densely spaced (micro)fenestral clotted laminae are binding thin laminae of partly dissolved grainstone. The structure is undulated (wrinkled) and calcrete fragments (clc) are also present. $\bullet$ I - an example of (micro)fenestral clotted laminite with strictly planar lamination; vertical section (left) and sub-horizontal section (right). $\bullet \mathrm{J}-$ a small ?Hermatostroma coenosteum with overgrowth by alternating ?Clathrocoilona and microbially clotted peels. Large bioerosion holes are probably ?Entobia (ent). The fills consist of small micritized grains and some (micro)fenestral clotted fabrics. - $\mathrm{K}$ - effects of episodic emergence of banks are recorded by calcretes separated by leached holes (ccr; arrows) and caliche-like recrystallization ghosts (left) or chalcedony-quartz (ch-Q; arrows) locally precipitated in amphiporids' skeletons (right). $\bullet \mathrm{L}-$ the packstones with abundant cryptalgal and microbial components contain numerous amphiporids which show a tendency to overgrow or coat them mutually. The very fine-grained geopetal fills (gpf) deposited in their axial canals; see also the thin-section detail with an ideal section across a stem of Amph. moravica (upper right). $\bullet \mathrm{M}-\mathrm{densely}$ structured ?Idiostroma-like stromatoporoids display at least three anomalies: The bedding-parallel arrangement, wide astrorhizal systems at each 5 mm layer, and sponge borings, ?Entobia (ent) completely filled by sediment. The astrorhizal systems contain winnowed fine-grained sediment adhering on the bottom of canals but not forming horizontal surfaces (like geopetal fills). $\bullet \mathrm{N}$ - some layers of sediment were basically fabricated by "felt" of interlaced thalli (tubular, with many transversal septa) of "Moravamminidae", Palaeoberesella-like algae (sub-horizontal section). This "felt" trapped and clotted fine sedimentary particles. $\bullet \mathrm{O}$ - the packstones with calcispheres, often associated with occurrences of large gastropods; shells were completely dissolved but some were covered by micrite envelopes which are preserved. The relevant depth marks in the Mokrá measured section are as follows. A and B 46.0, C and D 48.5, E and F 49.0, G and H 50.5, I 53.0, J and K 53.8, L 55.5, M 56.0, N and O $57.0 \mathrm{~m}$. 

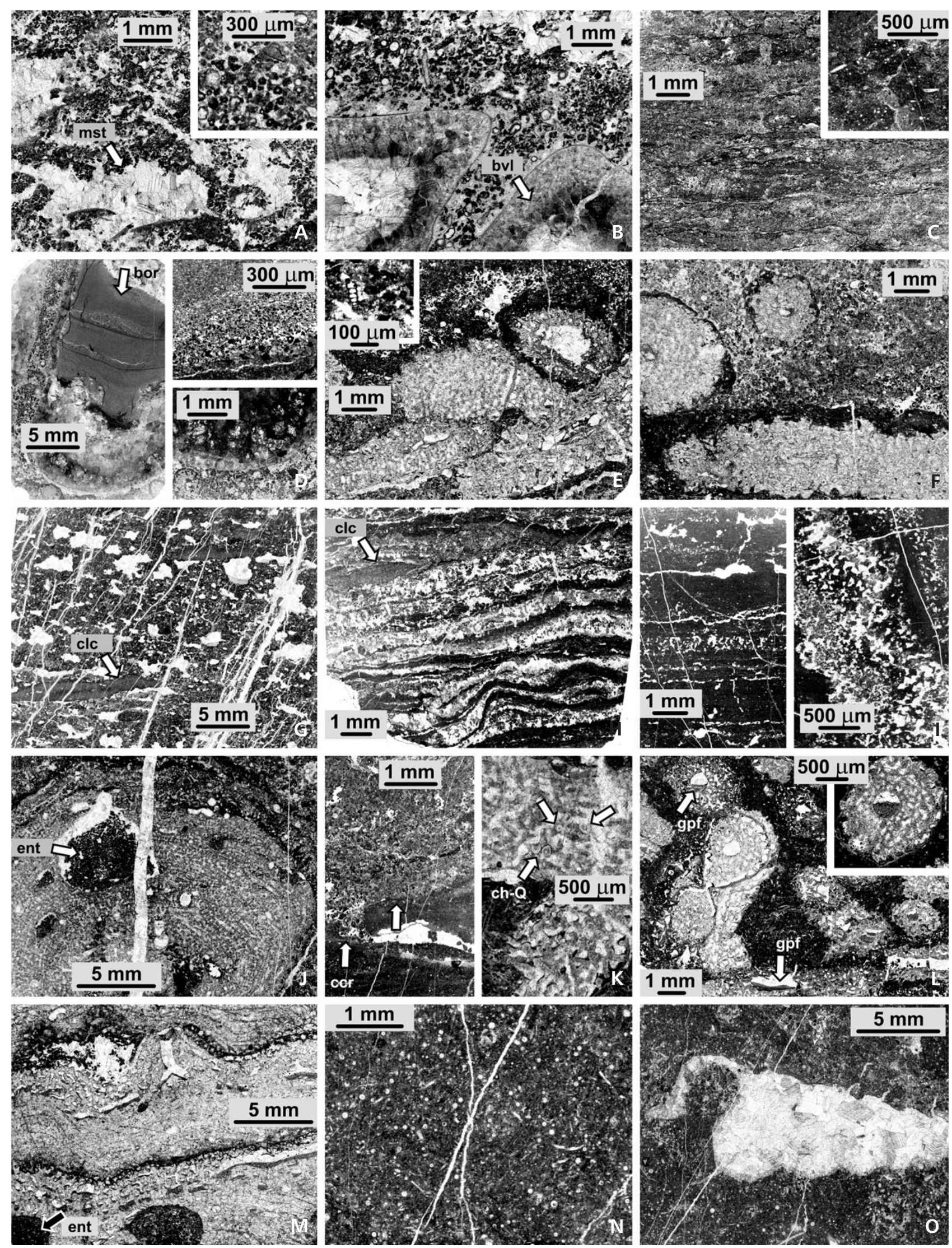
framework builders to rubble, sands and even stromatactis-bearing sediments. In this range, a number of other facies are indicative of environments between moats, reef flat, and reef front. Predominance of stachyodids is a principal feature of this exposed platform reef margin. Although these differences between the semi-sheltered flat ramp, lagoon and reef margin do not have a negligible role in the formation of specific reef facies mosaics and arrangement of different microfacies; Figs 3, 4 and 5), the overall lithological rhythms, thicknesses and architecture of the beds are quite similar (Fig. 6).

Eustasy. - The combination of microfacies signals with architectural signs allows us to make estimates of sea level fluctuations (Fig. 6). After vigorous shallowing and flooding at the E-MF base, three to four cycles can be traced in the lower half of the E-MF. These cycles can be traced mainly according to shallowing upward trends in the sediments, a fact which is quite unusual for platform reef environments in this area.

It may tentatively be concluded that carbonate production was not very high (Boulvain \& Wood 2007, Racki et al. 2008), particularly if this production is compared with rapidly expanding flooded surfaces which were controlled by these carbonate production and deposition environments. In this context, wastage in recycling environments also has great potential (Adey 1978, Eakin 1996, Perry et al. 2008) and was possibly employed in E-MF conditions of ocean water dysoxy.

Related to the four cycles in the lower half of the E-MF interval, the succession has several specific features. With the terminal stage of the first cycle, a thick series of shallowing and coarsening upward stromatoporoids-bear- ing banks were deposited. Relatively faster and stronger oscillation seems to precede the major shallowing shift, when secondary high-frequency oscillations were remarkably attenuated. This period was followed by an exceptional flooding which was recorded in these three sections just after the mid-level of the E-MF.

Typically, a series of thick event-deposited beds with trends towards fining and thinning upwards developed (Fig. 6). Then, the falling of sea level became slower, and irregularities in the storm generated sedimentary record slightly blur at least two cycles above the mid-punctata level. The next partial flooding episode came before the end of the E-MF, whereas the shallowest markers occur above the punctata-hassi boundary level.

Eustatic interpretation of other remarkable facies markers in the E-MF (stromatactis, Entobia): The occurrences of stromatactis sediments in the Svážná studna (and microstromatactis at Ochoz) coincide with a steep gradient between anomalous sea level fall and rise, A and B, after the mid-punctata stratigraphic level. Thus, the E-MF re-emergence of stromatactis-bearing sediments seems to be eustatically controlled.

The same seems to be true of sponge borings, Entobia, in stromatoporoid and coral heads (Mikuláš 1994, Tapanila 2006), but not in the limestone (Fig. 6). These occur particularly with (or after) the major destruction on the surface of platform reefs, with (or after) the major shifts in sea level setting (Fischbuch 1968, Hladil 1988); for the E-MF it is particularly with the mid-punctata and punctata-hassi levels.

The overall assessment of an approximate eustatic sea-level curve for the E-MF in the Moravian Karst suggests that there exists a visible difference between the

Figure 5. Ochoz; selected thin sections. - A - large irregular coenostea of Atelodictyon moravicum are scattered as "coral heads" in banks with amphiporids, disphyllid rugose corals and thamnoporid tabulate corals. Unbroken coenostea of this species lack commensalists as well as borers and are filled exclusively by sparite. $\bullet$ B - the surface of thick and branched Stachyodes paralleloporoides was often colonized by rugose corals and various epibionts. Micritic sediment contains numerous juvenile stages of amphiporids. $-\mathrm{C}$ - half-millimetre-sized peloids or ?pellets (pel) are rich in calcispheres and micritic clots. They occur together with well preserved (not abraded) amphiporids and gastropods (gad). Detail: also contained are many disc-shaped ?foraminiferal tests. They somewhat resemble ?Cribrosphaeroides but have small labyrinthoid pores above a thin dark layer on inner side of the test (upper left). • D - lumpy sedimentary fabric; calcispheres and large foraminifers (Cribrosphaeroides, Irregularina). $\bullet$ E - accumulations of calcispheres in dismicrite. Micritized subangular particles of fine silt size are also present. $\bullet \mathrm{F}$ - storm-deposited bed in deep inner part of atoll lagoon: Floatstone/packstone (according to scale) with highly heterogeneous (mixed) morphologies of amphiporid stems. $\bullet \mathrm{G}-\mathrm{a}$ redeposited fragment of a branched phillipsastraeid rugose coral lies in packstone where mollusc fragments are more abundant than those of corals, stromatoporoids and amphiporids. Tiny ostracods shells are admixtured with other submillimetre-sized clasts. $\bullet \mathrm{H}-$ abraded stems of amphiporids in packstone matrix. Small bioclasts in this matrix are almost exclusively tubular thalli of Issinella-"Moravamminidae" green algae. • I - a stromatoporoid stack based by Actinostroma crassepillatum with an overgrown attached rugose coral. $\bullet \mathbf{J}-$ an extremely good preservation of amphiporids with complete outer walls is typical for peloidal (?pelletal) sediments. The skeletal grains in patches of poorly-washed grainstone/packstone, with abundant calcispheres and Parathurammina foraminifers, are strongly micritized. $\bullet \mathrm{K}$ - a layer consisting of mechanically sorted, recrystallized and redeposited mixture of green algal thalli and (micro)detritus from amphiporid skeletons. Micrite was dissolved at a number of solution sutures where opaque residues were concentrated. - L - foraminiferal grainstone/packstone with dismicrite patches. Thick-skeleton amphiporids are abraded and their margins are micritized; thin-skeleton and widely opened amphiporids are also abraded but have no micritized rims. $\bullet \mathrm{M}$ - foraminiferal grainstone with marker components of Caligella foraminifers (lower right). $\bullet \mathrm{N}-\mathrm{a}$ resedimented grainstone lamina, with skeletal and rock fragments altered to various degrees, covers a hardened, fine-recrystallized surface. • O - amphiporids (amp) with "archetype" morphological traits (such as Amph. pervesiculata, or Amph. pinguis) occur together with Stachyodes costulata (sta; in a separate window, on the right). Increased abundance of brachiopods (bra) and ostracods (ost) are an epiphenomenon to local emergence of the above mentioned fauna. The relevant depth marks in the measured Ochoz section are as follows: A and B 16.0, C to E 15.0, F and G 13.8; H 13.5, I 10.0, J 9.0, K 8.0, L 6.0, M 5.0, N 4.0 and O $2.3 \mathrm{~m}$. 

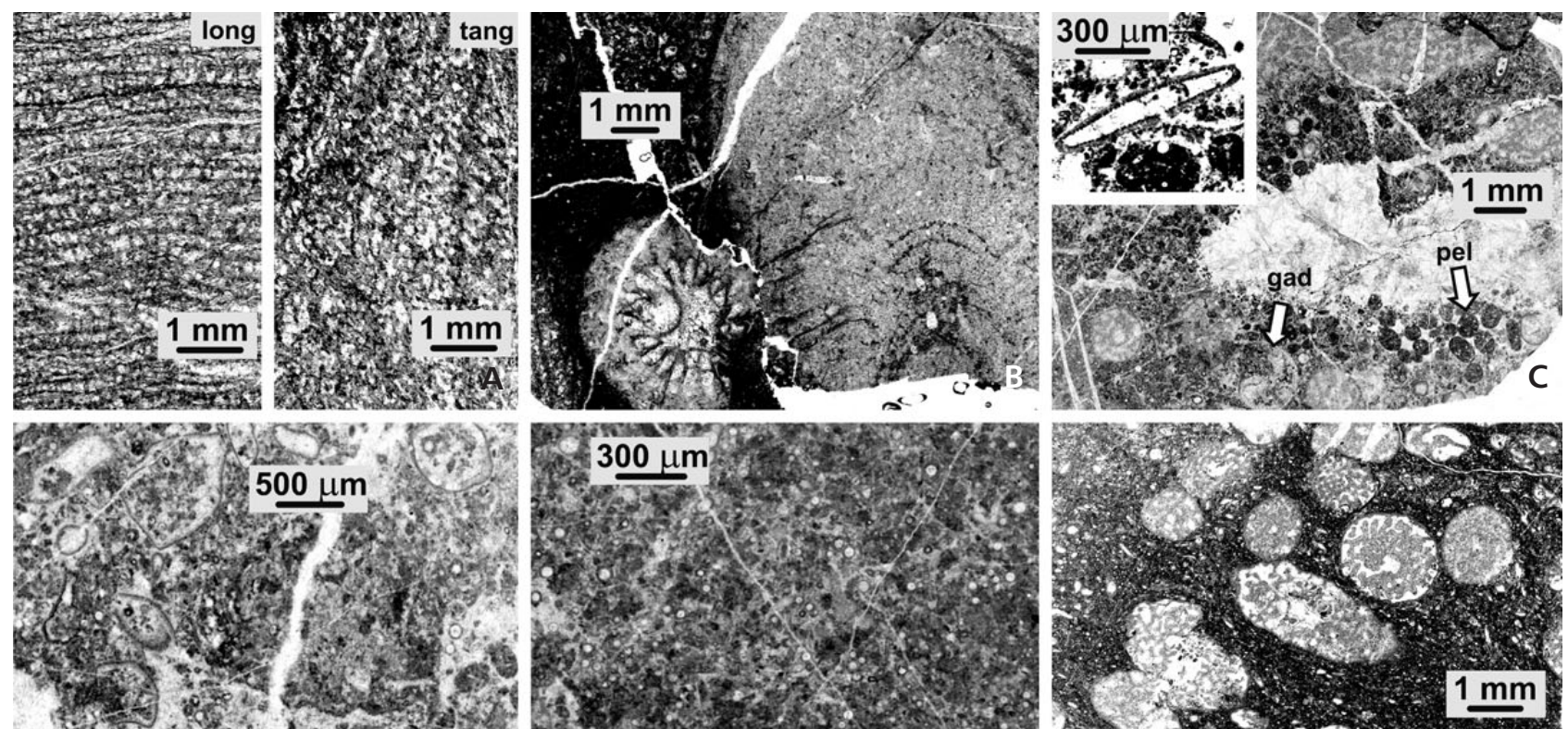

4. 2 . 60
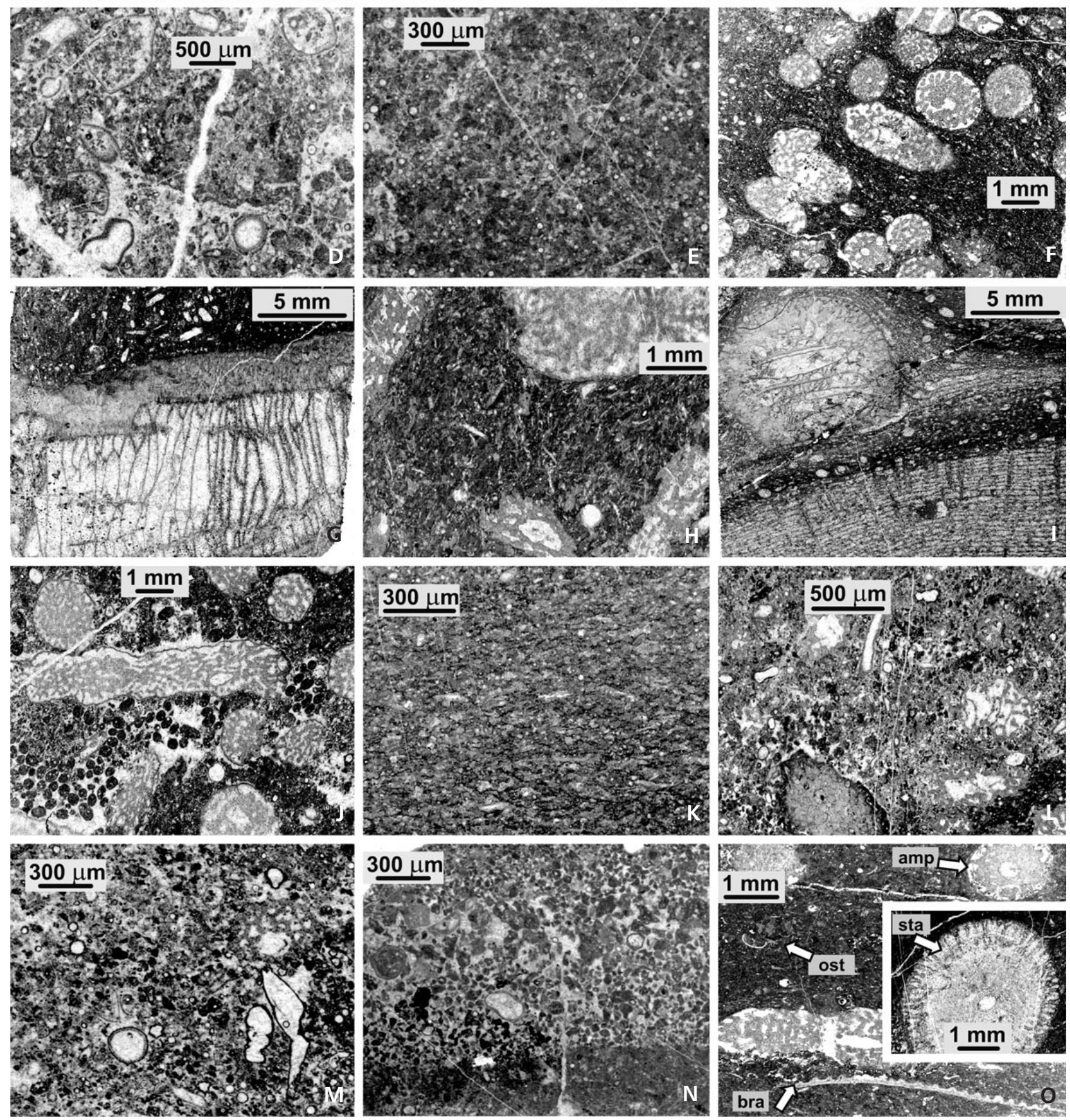
structures/patterns at the base or end of the E-MF and those which occur at (or close after) the mid-punctata level. The normal development of quasi-cyclical patterns with a hypothetical frequency of $1 \mathrm{Ma}$ (for the whole E-MF) and $100 \mathrm{ka}$ (between), both $\pm 30 \%$ (Hladil 2002), seems to be disturbed in the middle of the E-MF. Hence, the lithological and biological evidence suggest that the mid-punctata level has an anomalous structure.

Stromatactis. - The occurrence of stromatactis and stromatactum sedimentary fabrics are environmentally very sensitive (Hladil et al. 2007) and deserves special attention. The stromatactis sedimentary facies are not very typical for the reef environments and they form rather thick lobes and waves (mounds) in deeper environments which have sigmoidal beds and all the signs of repeated rapid sedimentation (Hladil et al. 2008a). In addition, these sedimentary forms are mostly related to time spans with reduced shallow water reef development, ramp morphology and bacterial-sponge invasions on the shelf, and eustatically they signify transgressive system tracts (TST) with recovery from a significant lowstand or catastrophic damage and reshaping of the reef systems.

A conspicuous re-emergence of stromatactis was documented mainly in Belgian E-MF (Boulvain 2001, 2007), where the $\mathrm{cm}-\mathrm{dm}$ sized stromatactis were correlated with the lower third of the punctata conodont zone, in the lower part of the Arche mound member. The initiation by the E-MF sea level rise was inferred from sequential architecture of the formations. After a short period of demise, stromatactis occurred again in the newly defined La Boveire Member (Boulvain \& Coen-Aubert 2006). Although it is in the late part of E-MF (punctata), which is generally marked by a trend to shallowing and increased dust and overall detrital input (Hladil et al. 2006a, Racki et al. 2008) these second levels correspond to some partial TST-HST. Therefore, the thicknesses are smaller. Other stromatactis occur above the base of hassi Z. (in Lion Mb.).

In proportions of thicknesses and time, a question arises whether this significant dividing line at the base of La Boverie lies very high within the upper part of the punctata Z., as indicated by smaller thickness of these mounds, or could tentatively be aligned with the levels just above the mid-punctata disturbances, in consideration of certain stratigraphic condensation of these upper parts. However, the Macgeea-Sinodisphyllum fauna that mark both the Belgian La Boverie Mb. and Moravian Karst post-anomaly beds at Svážná studna suggest that the second of these two possibilities cannot be ruled out.

If a very simplified structure of Belgian stromatactis occurrences is used, we can deduce a three-level image with stromatactis above the basal, ?middle or upper and topmost levels of the E-MF interval. Contrary to Belgian settings, the E-MF beds of the Moravian Karst were always considered to be something special and were traditionally understood to be stromatactis free facies assemblage. In fact, they are not completely absent, but they are minimized, due to absence of typical large scale or wide ramp environments. This change of knowledge regarding Moravian stromatactis was caused by recognition of the localization of $\mathrm{cm}$-sized stromatactis in limestone lenses along the damaged reef margins of mid-E-MF times (J. Otava, Svážná studna; Hladil et al. 2006b; Fig. 6).

Sporadic occurrences of small stromatactis-bearing lenses were also found through thin sectioning in Ochoz lagoonal limestones, with the mid-punctata anomaly and also punctata-hassi boundary level. In comparison with Belgium, there remains only the lack of stromatactis just above the E-MF base.

To conclude, these scarcely visible stromatactis links between different carbonate depositional systems in Moravia and Belgium (Hladil 2002, Boulvain 2007; Fig. 2) can lead to new hypotheses regarding inter-regional controls of the environment. It is remarkable, that the limestones with stromatactis are always very pure, with the lowest contents of non-carbonates. Therefore, the characteristic stromatactis-forming material (Hladil et al. 2006b, 2007, 2008a), which was hydrodynamically separated and finally dumped from the medium dense collapsing mixtures on its downslope trajectory, had to be originally collected in very pure parts of submerged highs and on the upper slope.

Definitely, the washing off and/or a bypass zone for impurity must be employed, because otherwise it would be very problematic to eliminate the mineral dust input compounds in the rare relatively shallow locations and particularly the riverine fine-detrital input in the zone below the storm wave base, where the limestones with stromatactis fabrics are most commonly located. And finally, the hypothesis can be tested in parallel to conclusions by Hladil et al. (2008a) that a significant part of stromatactis formations develop in relationship to TST conditions which were preceded by high-amplitude eustatic variations during long-term lowering of the sea level. In spite of the overall greenhouse effect and high sea level conditions in the Givetian-Frasnian (e.g., Copper 2002), such a relative lowering in the Late Givetian and ?Early Frasnian seems to be inferrable from the most recent datasets (evaporite pseudomorphs in Fromelennes, reduced overall carbonate production, etc., Boulvain et al. 2008b).

Magnetic susceptibility. - The stratigraphic variation in MS values was studied in Mokrá and Ochoz sections using the powerful method of grid data (mesh sampling). The data from several previous research campaigns (Hladil 2002, 2007; Geršl \& Hladil 2004; Hladil et al. 2006a; Boulvain \& da Silva 2006; Nawrocki et al. 2008) were compared with this new data (Fig. 7). The relationships 
Mokrá, Quarry West

Ochoz, Skalka Quarry

(shallow, gently inclined ramp) (large and deep lagoon, in reef complex) ASSESSMENT OF DEPTH - SEDIMENT COMPOSITION, FABRIC, EARLY DIAGENESIS

ESTIMATES ABOUT WATER DEPTH (combined)

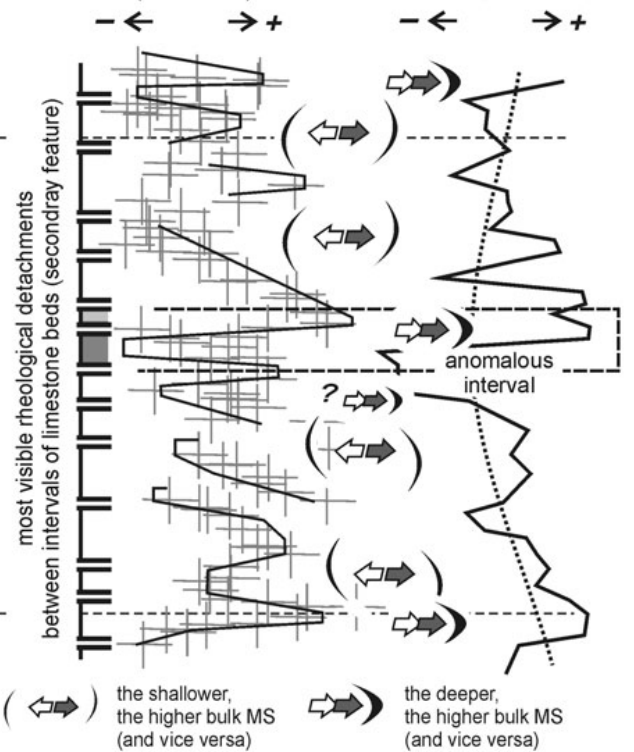

BULKMS, AVERAGE MAGNITUDES (combined, simplified, shapes only)

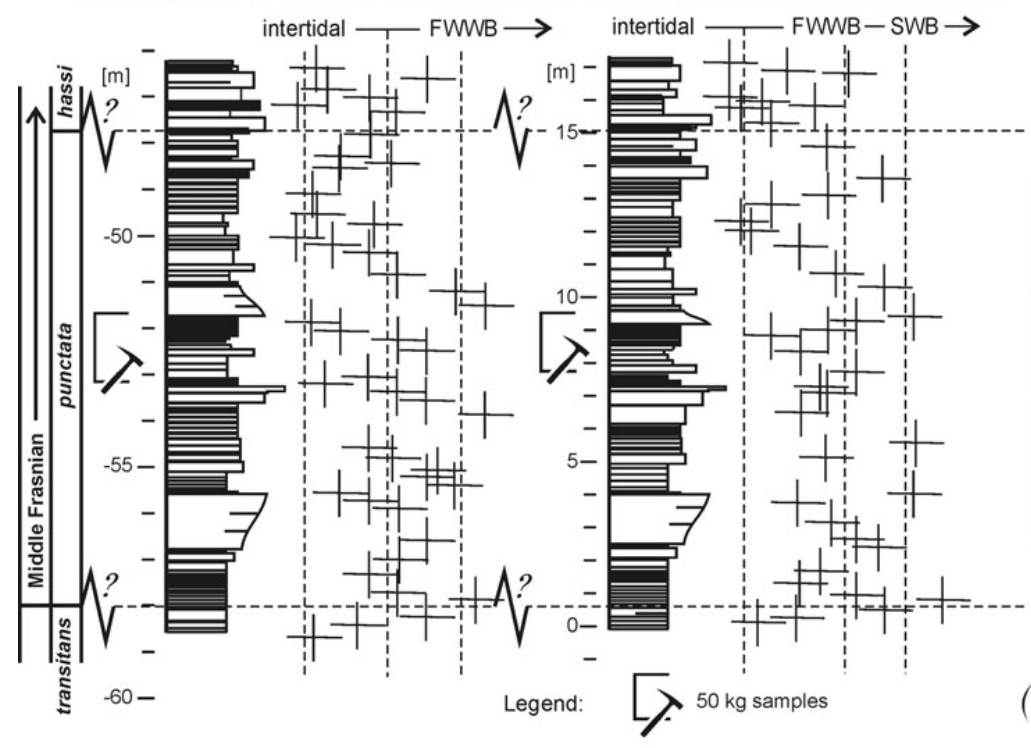

SELECTED MARKERS OF ORIGINAL DEPOSITIONAL FACIES (vertical successions and principal cross-relationships at time levels)

\section{Svážná studna Cave (outer reef)}

(1)

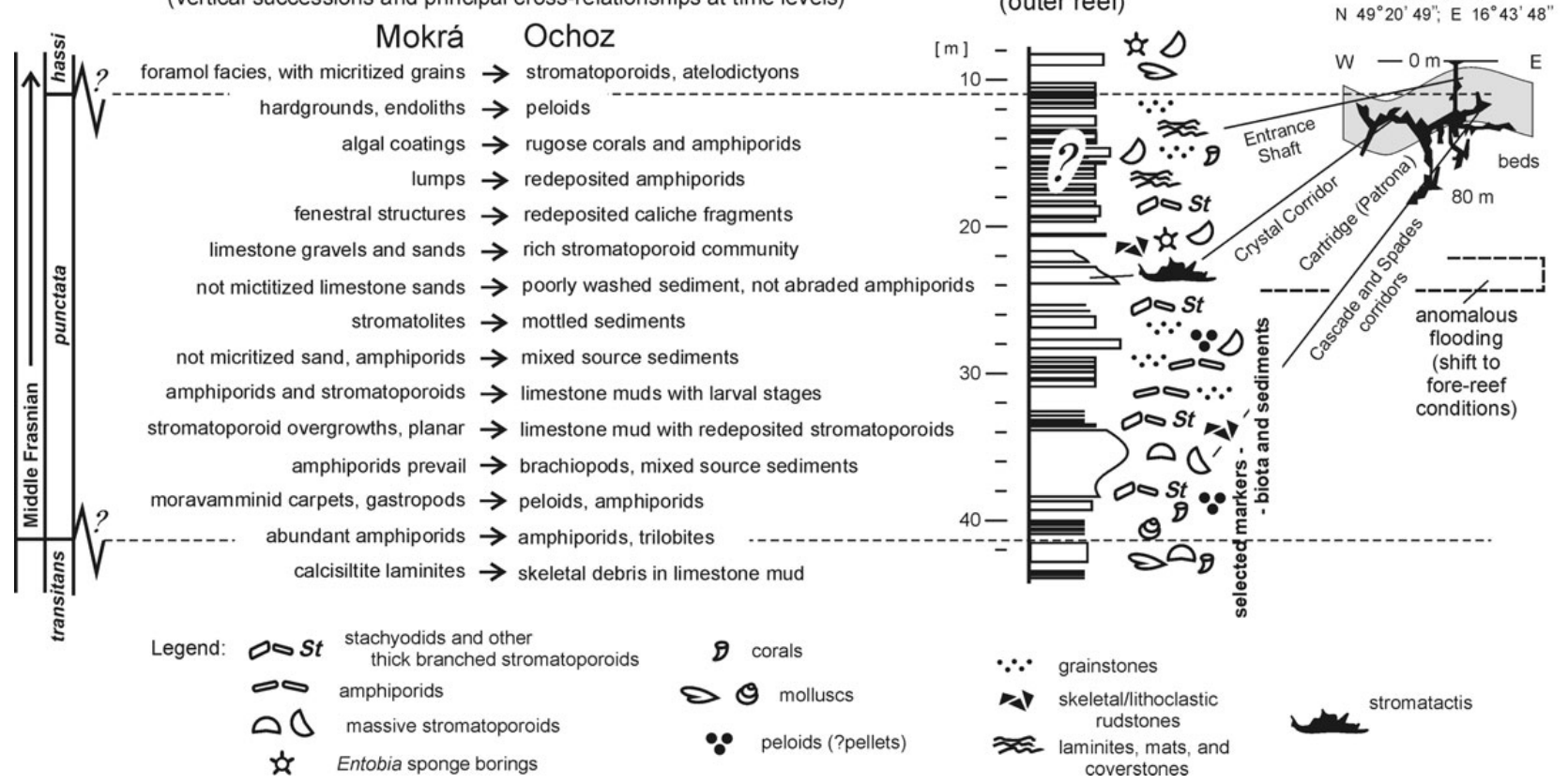

Figure 6. Facies and interpreted sea level fluctuations: illustrated on the background of simplified stratigraphic columns of the Mokrá, Ochoz and Svážná studna (Moravian Karst) sections. Upper part of the figure: all available paleoenvironmental indications from slabs and thin sections were expressed by relative positions of points (+) along the depth axis, from intertidal to fair weather wave base (FWWB) and storm wave base (SWB). Further to right, the obtained variations were combined for these sections, and the relevant trends were suggested (lines). Note that the mid-punctata interval displays an anomalous MS to system track (ST) relationship. Lower part of the figure: in spite of different faunal and lithological expression (= environmental mosaic), the time correlation scheme of main features is meaningful and can serve as a loop check (lower left). The third Svážná studna section was studied only by means of non-destructive in-situ methods (cave; nature protection).

between MS values with mineralogical characteristics and $\mathrm{K}$, Th and $\mathrm{U}$ related ratios are indicative of prevalent paramagnetic-type carriers of magnetism, and these con- clusions were also directly confirmed by means of magnetomineralogically-orientated magnetic measurements (Hladil 2002, Hladil et al. 2006a). 
The completed datasets on E-MF rocks suggest that the $\mathrm{Th} / \mathrm{K}$ values point to unusually strong relative growth of Th concentrations in these carriers with remarkable MS and chemically detected positive shifts in impurity contents at the mid-E-MF (mid-punctata) and uppermost E-MF (punctata-hassi) levels. Although this fact can be considered in a normal interpretative approach for the latter case, a eustatic low stand of the ocean and higher proportion of delivered coarse mineral dust suggest that the interpretation of the former case is more problematic. This is owing to the fact that the mid-punctata level has a slight flux of impurities in general, and, in addition, the identified carriers of these magnetic and chemical properties defy the normal eolian dust compositions.

The main MS characteristics of the E-MF interval are: smoothest MS trend line for the E-MF interval is a left-bow-shaped curve where the highest MS values are approximately at the lower and upper points. This bow or cycle pattern was inferred also in previous and concurrent studies (Hladil 2002, Nawrocki et al. 2008). Furthermore, the robust vertical and horizontal averaging of data (Fig. 7, upper right) revisited and revealed the highest amplitudes just at the mid-E-MF levels (Fig. 7). The remarkably developed depression-and-elevation around this level is marked in logs by letters A and B. This A-B pattern (corresponding to pattern 1 , Geršl \& Hladil 2004) is specific in its inverse relationship to a eustatic sea level curve. And equally anomalous is the relationship of this A-B pattern to stratigraphic MS variations below and above (Fig. 7).

Whilst the MS curve in the lower and upper parts of the E-MF interval has a quite normal appearance for the records of rhythmically fluctuating dust delivery, its middle part is undoubtedly an anomalous record. The anomalous mid-E-MF pattern has wide inter-regional implication if compared with medium distant basins in Belgium and Poland (Boulvain \& da Silva 2006, Nawrocki et al. 2008, and relevant datasets shared by the authors). Its shape identifies an event (or crisis) pattern - resembling the MS structures which were repeatedly documented even with the major Devonian crises (Choteč, Kačák, Upper Kellwasser; Hladil et al. 2008b). The latter particularly relates to MS to eustasy relationships which are opposite to the normal regimes of dust trapping in pure limestone on platform reefs where the crisis state is low MS with lowstand and high MS with highstand (Hladil et al., op. cit.).

To conclude, the high-resolution MS stratigraphic correlation in limestones provided proxies for evolution of the E-MF dust input and was confirmed to have efficiency in assessment of normality or abnormality of supra-basin environmental settings in stratigraphic detail. This second procedural step that was carried out after the bio-litho analyses has drawn our attention, even more particularly, to answering the questions about the mid-E-MF anomaly.

Gamma-ray spectrometry. - The overall natural gammaray (NGR) stratigraphical variations in the E-MF in Mokrá and Ochoz sections are comparable to the pattern segments E/D and D which were extracted from the HV-105 Krrtiny borehole (Geršl \& Hladil 2004, fig. 3 of the cited paper).

Beside the elevated NGR values at the base and top of the E-MF, two other maxima exist in this interval. The first occurs in the middle of the lower part of the E-MF and corresponds to a series of thin beds which cover the underlying first massive boundstones in the sections; its explanation remains problematic. The second elevation corresponds to thin beds below the mid-punctata flooding surface with overlap to above-lying, abruptly deposited beds; it is at the elevation that corresponds to the anomaly defined by bio-litho and MS logs.

The GRS curves for Th, $\mathrm{K}$ and $\mathrm{U}$ concentrations in measured sections illustrate that $\mathrm{Th}$ is most relevant to the shape and position of this anomaly. Elevations in $\mathrm{K}$ contribute irregularly to the curve and $\mathrm{U}$ concentrations are typically increased in the upper part of the anomalous interval (Fig. 8). Overall increase and decrease in NGR ( $\gamma$-tot) and GRS values correspond with the changes on the MS curve (Fig. 8).

In spite of considerable variations in the resulting image, the observation of almost jointly elevated Th, K and U, and particularly Th-marked values, suggest two practical possibilities: Firstly, this can be indicative of scatter of $\mu \mathrm{m}$-sized grains, rather than nm-sized altered, clay, oxidic and mud impurities, or secondly, this can be caused by deposition of upper crustal rock particles, as K, U and Th are markedly concentrated in granite-and-sandstone rocks compared to a basalt rock suite. However, such a possibly coarse particu-

Figure 7. Typical plots exemplifying the variability and stability of E-MF magnetic-susceptibility stratigraphy patterns. Previous works in the Moravian Karst (upper left), from left to right: Slightly moving averages and moderate spline (related to basic data on regularly spaced points); data plot based on parallel and horizontal sample rows (= grids), averaged to $0.5 \mathrm{~m}$ spaced points); one example of moving normalization plots (irregularly grid-strengthened, $0.1 \mathrm{~m}$ ). The curves in upper right are the most robust recent visualizations of the completed MS data in grids, averaged to $0.3 \mathrm{~m}$ points. All these data and methods of processing allow separation of the anomalous, mid-punctata-zone pattern A-B. Similar patterns can be traced in data sets from other European areas as concurrently developed by other researchers and sent for comparative purposes. In spite of complications from uncertainties with fluctuating sedimentary rare, an attempt to construct a hypothetical mean pattern is shown (lower right). The A-B pattern is codefined by its actually inverse position when MS is compared with ST (see Fig. 6). 
MS plots in "punctata"-Z. correlated interval in Moravian Karst

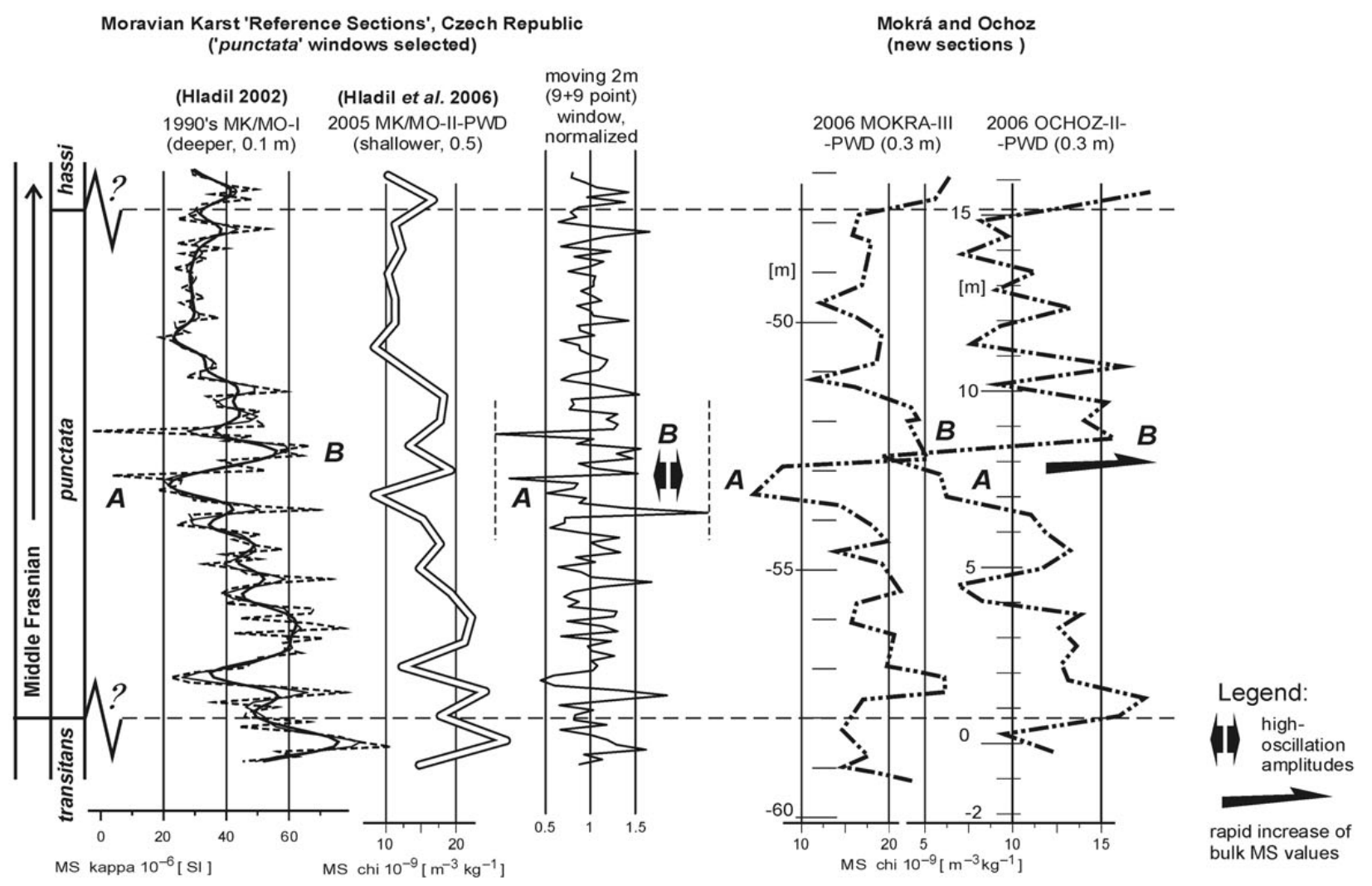

For comparison, examples of relevant MS logs from other basins

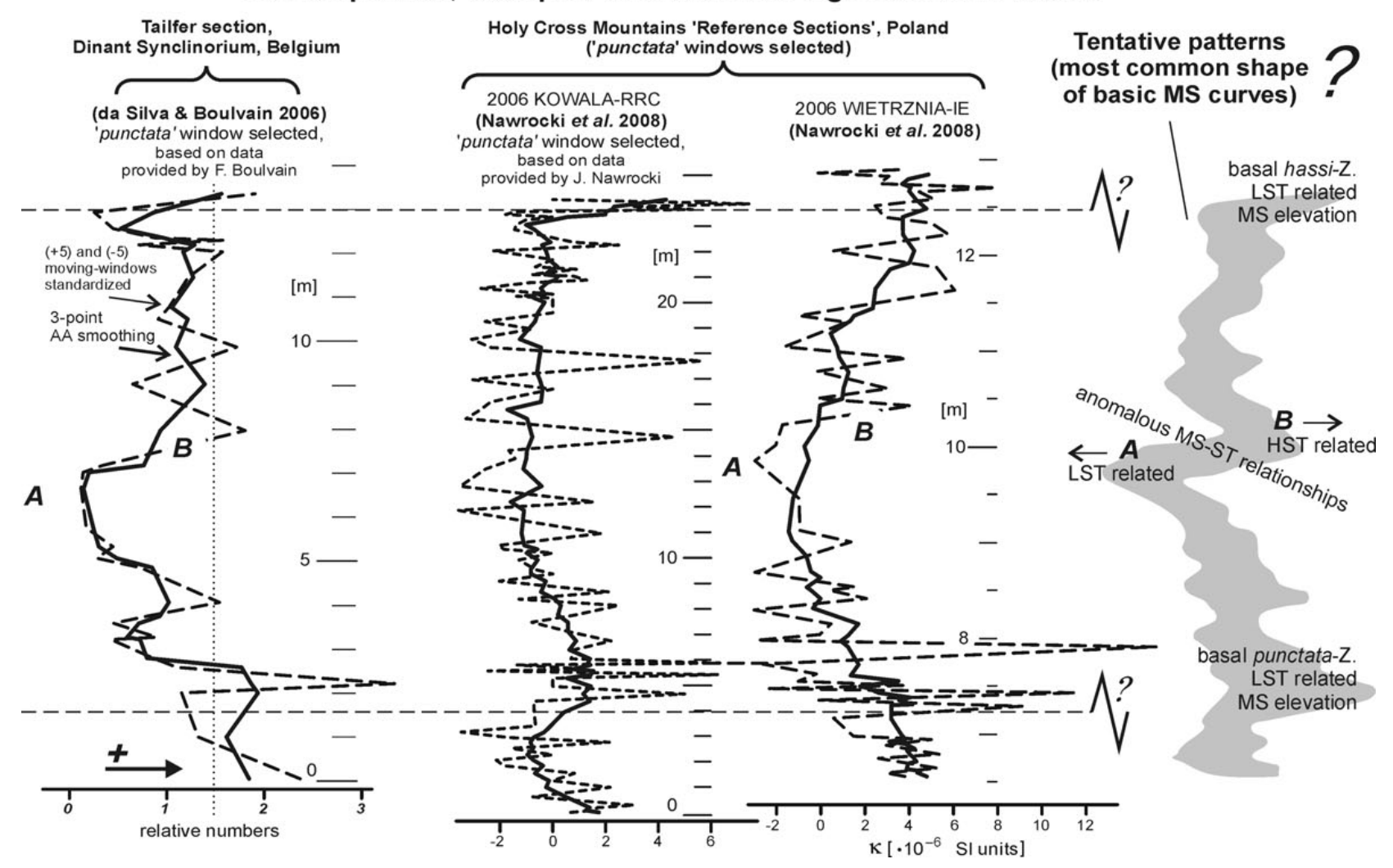


late scatter is contrasting to an absolute minimum overall eolian flux, as well as distal delivery conditions for any terrigenous detrital grains from the riverine environments or local highs (Hladil et al. 2006a). Relatively increased amounts of all these three components were found higher, near the punctata-hassi boundary, but certainly not more towards the inner parts of the E-MF interval. In summarizing these interim results we can conclude that the GRS studies suggested that the mid-E-MF impurity material contains material of suspect origin.

Instrumental neutron activation analysis. - With the measurements by means of INAA, the following elements were analyzed: $\mathrm{Ca}$; K, Fe, Na, Ba, Sr; REE from $\mathrm{La}$ to $\mathrm{Lu}$, and a selection of trace elements $\mathrm{Zr}, \mathrm{Co}, \mathrm{Cr}, \mathrm{Hf}, \mathrm{Rb}, \mathrm{Cs}, \mathrm{Sc}$, Ta, Th, U, As, Ni, Sb, Zn, Ga, Br, W, Hg. Our study presents two relatively new approaches to processing and visualization of the geochemical element concentrations which are related to complex impurity in limestone: Firstly, abundances of 35 major, trace and ultra-trace elements were normalized to their averages in the E-MF. This recalculation revealed a considerably homogeneous (correlative) band if these values are plotted. Some specifics were found only for behaviour of $\mathrm{U}, \mathrm{Sb}$, As, for example (Fig. 8). In most general terms, these concentrations show a significant increase aligned to NGR high in the middle of the lower part of the E-MF. This is interpreted as the impurity being distributed homogeneously in the rocks and not separated into pockets or sutures detectable only by GRS.

On the other hand, the mid-punctata anomalous interval, characterized by strong responses in MS and GRS, starts with the lowest possible concentration values and these values increased very slowly over a long interval of time. It must be emphasized that there is an almost absolute negative correlation between these concentrations made on small samples and large-volume GRS. A similar, although not quite identical trend can be inferred from comparison of standard-row with grid-extended, robust MS data (Fig. 7, upper left to upper right).

The reason for this discrepancy in concentrations derived from small samples and large volume samples was revealed by careful examination of rock structures in situ. It is caused specific distribution of impurities in limestone; it means that the impurities in this anomalous interval are preferentially concentrated in small lenses, pockets and solution sutures. This conclusion was also confirmed by means of X-ray mapping and radiography (Hladil et al. 2006a).

In the second approach, we used potassium as a marker for the most generally distributed natural impurities, both generally (Hladil et al. 2008c) and on the Givetian-Frasnian platform reefs (Hladil et al. 2006a). Therefore, the relative compositional behaviour can be shown using the normalization to $\mathrm{K}$ (i.e. after the recalculation, the $\mathrm{K}$ concentration will be 1 , from first to last). In this way, we can more easily distinguish between material with addition of anomalous compounds and quasi-normal background compositions related to the complex impurity in limestone. In spite of the observed fact that the higher contents of impurities may often correspond to a relative surplus of all other elements compared to $\mathrm{K}$, the suspect (anomalous) mid-E-MF stratigraphic level shows significant differences (Fig. 8). In proportion to K, there is an extreme and structured over-abundance of Fe, trace and rare elements.

The diverseness above the mid-lower part of the E-MF introduces yet another unsolved problem. The latter is particularly due to the fact that enhanced Sb-As-W concentrations occur, but a relative surplus of these, plus other trace elements, were found only in the Ochoz lagoon (Fig. 8; lower right, $\sim 4.7 \mathrm{~m}$ ). It is at the levels where the initial strong E-MF flooding phases still took effect and absolute concentrations of impurity were smaller than average and further decreased. Combination of Brunnia sources and effects of dysoxic water might have to be considered. Also the U (and U-Ba) excursions at mid-lower and mid-upper parts of the sections have been sufficiently separated using the latter method.

Iridium. - Elevated concentrations of Ir up to $1.5 \mu \mathrm{g} / \mathrm{kg}$, which is 10-100 times higher in comparison with the background limestone, are disseminated in these sections. In no instance were these anomalies observed to strictly adhere to defined thin horizons; however using the coarser $(\mathrm{dm}-\mathrm{m}) \mathrm{scale}$, the concentrations of increased values seem to mark mainly the mid-E-MF (mid-punctata) anomaly and one other interval above the punctata-hassi boundary (Fig. 8). The consistent and solid geochemical evidence of these elevated values relates to mid-E-MF in Mokrá, and punctata-hassi in Ochoz.

The stratigraphically spotty and repeated occurrences of slightly increased Ir concentrations in 2-3 intervals around the mid-E-MF level suggest two essentially opposing hypotheses: Firstly, this can be a record of several suspect events in a row, and secondly, it can be caused by infiltration and resedimentation of Ir-rich impurity material. Geochemically, these slightly elevated values are coupled with slightly elevated values for $\mathrm{Cr}$ in both outcrops (to 3-7 mg/kg), but no significant correlation was found for example with $\mathrm{Ni}$. The assessment of these small anomalies is further complicated by the complex structure of $\mu \mathrm{m}-\mathrm{nm}$ non-carbonate impurity objects, as well as the overall predominance of normal dust-related impurities.

It is therefore very complicated to interpret and understand the situation. At the present stage of investigation, the elimination of factors concerns only three conditions: (1) no Ir-rich grains in the size category equal to or exceeding $63 \mu \mathrm{m}$, (2) no visible correlation between Ir content and 


\section{ELEMENT GEOCHEMISTRY} (INAA, whole-rock data)
OVERALL GRS-MS ANATOMY OF "MID-PUNCTATA" ANOMALY

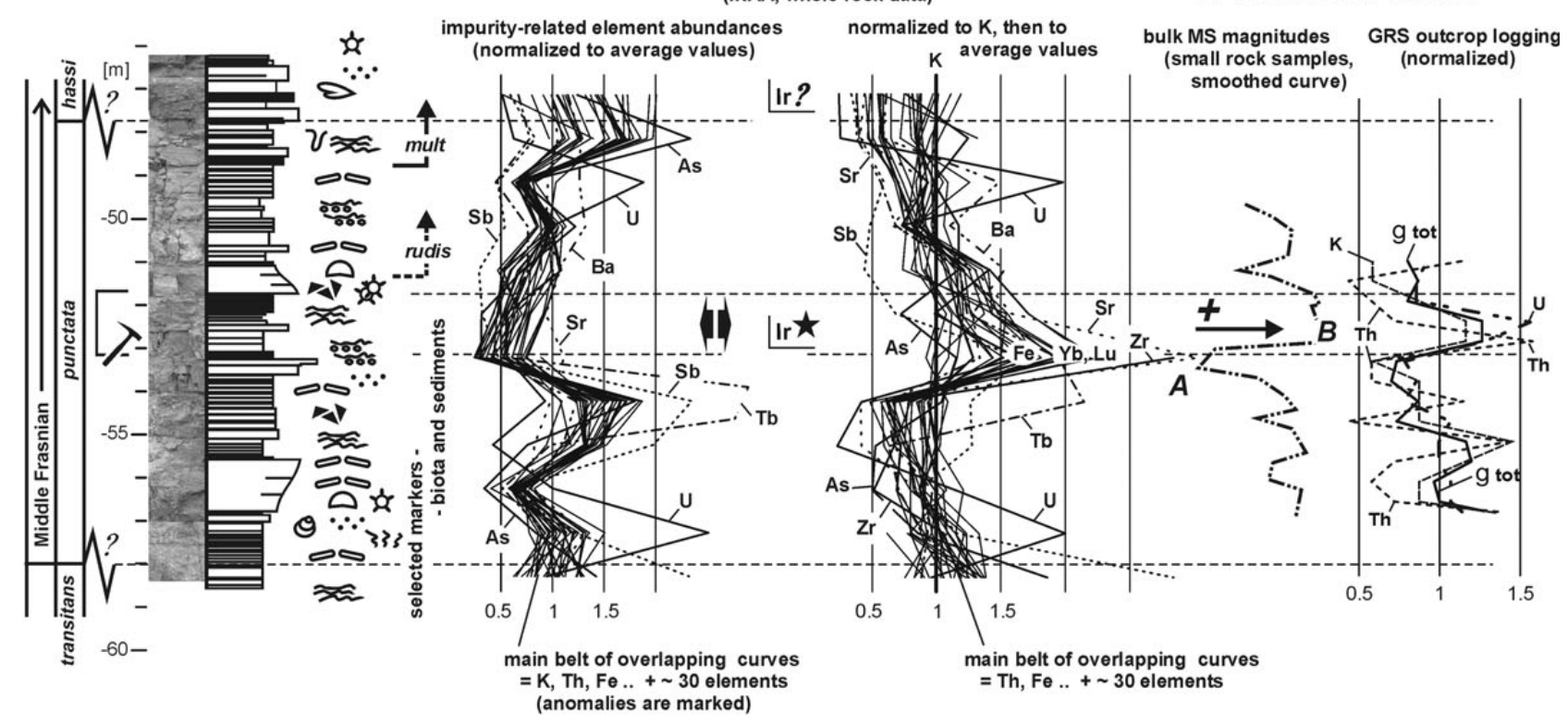

Ochoz, Skalka Quarry - reef complex, lagoon - higher sedimentation rate, very pure limestones

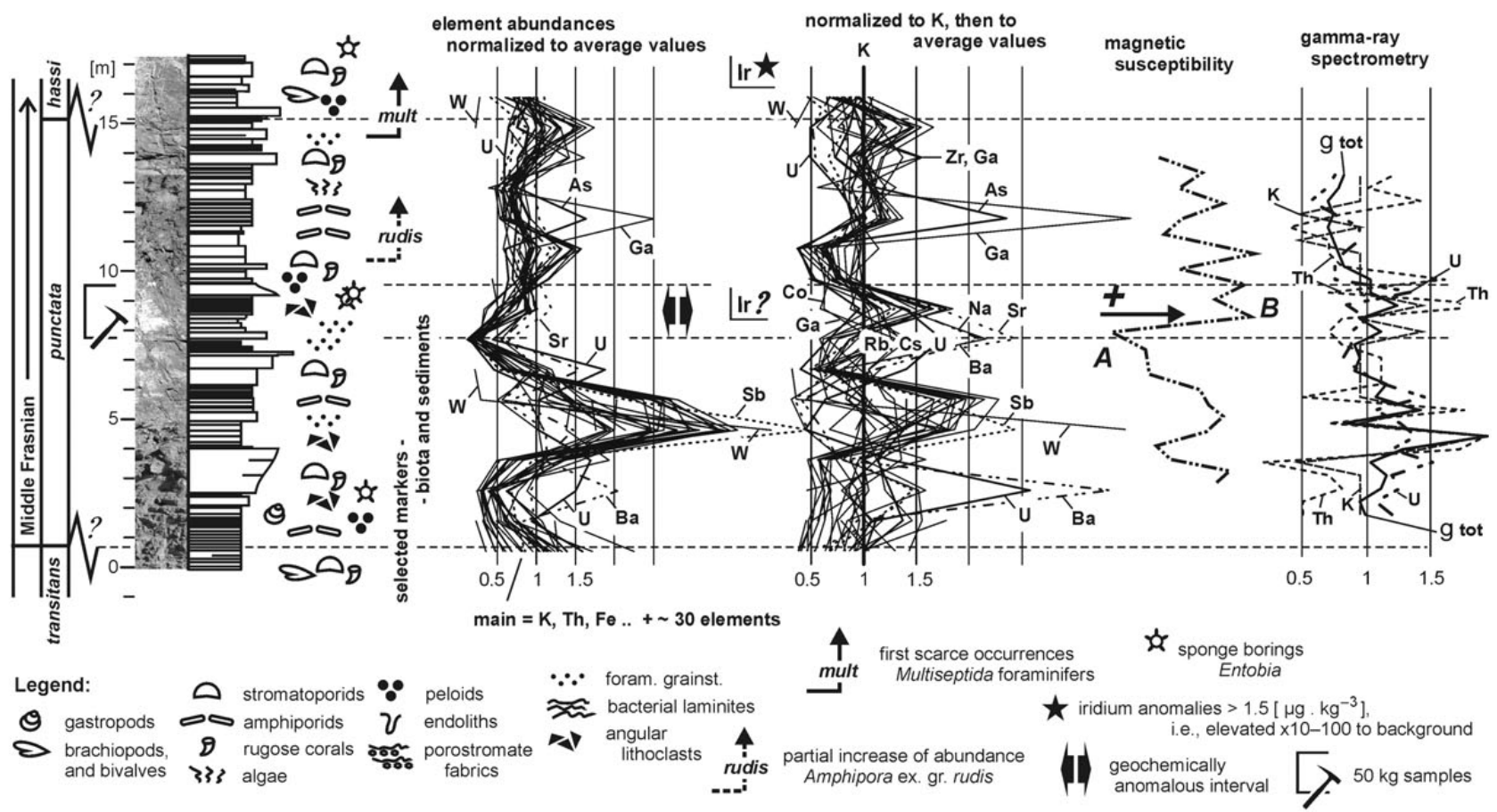

Figure 8. Integrated features of changing chemical element concentrations in the Mokrá and Ochoz sections. The results of normalization to both the local E-MF averages and potassium contents are plotted on the background of lithological, faunal, MS and GRS parameters. The mid-punctata anomaly is characterized by low concentrations found in small samples (INAA) but high ones in large volume material (GRS); it is indicative of the presence of spots and sutures with re-concentrated impurity components; high concentrations of $\mathrm{Fe}$ and trace metals compared to $\mathrm{K}$ are indicative of exotic silt components.

amount of total organic carbon, which are slightly varying, low TOC contents, about 0.1 and 0.2 wt.\% for Mokrá and Ochoz, respectively, and finally, (3) bacterial/algal mats and stromatolites (Mokrá) were not the principal collectors of platinoids.
Carbon and oxygen isotopes. - In comparison with the robust $\delta^{13} \mathrm{C}_{\text {carb }}$ positive anomaly which was interpreted for almost the entire E-MF interval (Yans et al. 2007, Racki et al. 2008), the shallow water areas on platform reefs of the Moravian Karst area reflected continuous shifts to a lesser 
degree. The main information concerning very high $\delta^{13} \mathrm{C}_{\text {carb }}$ positive shifts relates mainly to fore-reef facies, not to the area-extensive platform (Hladíková et al. 1997, stratigraphically revised and completed by Geršl \& Hladil 2004). The study from 1997 unveiled a strong $\delta^{13} \mathrm{C}$ isotope excursion to $+5.5 \%$ VPDB, in dark-grey to blackish calciturbidites drilled from the $\mathrm{HV}-105$ Krrtiny well, depths 252-276 $\mathrm{m}$. The mean values for $\delta^{13} \mathrm{C}$ and $\delta^{18} \mathrm{O}$ surrounding this anomaly in E-MF near Křtiny are $+2.0 \%$ and $-4.5 \%$ o, respectively.

The isotope records for the Mokrá and Ochoz sections differ from Křtiny. Mean values for Mokrá E-MF are $\delta^{13} \mathrm{C}$ $+0.1 \%$ and $\delta^{18} \mathrm{O}-5.7 \%$. There is no increase in $\delta^{13} \mathrm{C}$ values from the lower to upper part of the E-MF, only the mid-E-MF has a slight elevation to $+0.2 \%$ o. Practically the same can be said of quite steadily fluctuating values in the Ochoz E-MF, where the most common values for $\delta^{13} \mathrm{C}$ and $\delta^{18} \mathrm{O}$ vary at $+1.8 \%$ and $\delta^{18} \mathrm{O}-6.2 \%$, respectively.

However, there is one distinctive disturbance in the latter section which relates to a major drop in the middle of the lower part of the E-MF in thin beds above the lower stromatoporoid beds; levels are comparable to INAA-MS-GRS peaks (Fig. 8). In this place the values drop by as much as to $\delta^{13} \mathrm{C}-2.0 \%$ and $\delta^{18} \mathrm{O}-8.1 \%$. The calculated correlation values between parallel variations in $\delta^{13} \mathrm{C}$ and $\delta^{18} \mathrm{O}$ at Mokrá and Ochoz are slightly positive, 0.15 and 0.31 , respectively.

The negative and positive shifts in $\mathrm{C}$ and $\mathrm{O}$ stable isotopes are often (not always) coupled unidirectionally, i.e. higher values in $\mathrm{C}$ are accompanied by higher values in $\mathrm{O}$. This coupling is obviously different from that which was found for the fine isotope stratigraphic sequences in the Moravian Karst in general - i.e. each rise or fall on the $\delta^{13} \mathrm{C}$ curve is accompanied by an opposite change on the $\delta^{18} \mathrm{O}$ curve (mushroom-shaped fine-sequence pattern - Hladil \& Hladíková 2000). One of the main findings of this isotope data review is therefore concerning the absence of any significant $\mathrm{C}$-and-O isotope signatures for the shallow-water record of the refined mid-E-MF (mid-punctata) stratigraphic level.

Rare exotic particles. - The extraction of particulate impurities was the critical step of the mid-punctata anomaly verification. Fifty-kilogram samples from Mokrá and Ochoz sections were used for these purposes (see Methodology and datasets). From the results of these procedures, it was found that the extractable non-carbonate particulate lithic (allochthonous) fraction corresponds to $2-3 \mathrm{~g} / \mathrm{kg}$. Estimates of loss are about 50-60 wt.\%, and this loss corresponds to weakly separable nm- $\mu \mathrm{m}$-sized impurity aggregates, e.g., when fine-crystalline quartz or recrystallized phyllosilicates make the complex-impurity-to-particle boundaries fuzzy. It means that the amount of these relatively coarse particulates is slightly less than $1 / 10$ of all embedded impurities.

The allochthonous non-carbonate particles often correspond to altered lithoclastic/crystalloclastic upper crustal rocks, with a dominance of quartz, feldspars, and phyllosilicates, with a fine scatter of Fe-oxides in aggregates and lattices, so that they do not provide very specific information about the provenance in this size fraction. However, the overall characteristics of these materials do not contradict the possible hypothesis that this material was delivered from and across the Laurussia, with a proportion of globally dispersed dust ( $c f$. data by Hladil \& Bek 1999, Janoušek et al. 2000, Hladil et al. 2006a).

Figure 9. Examples of larger specimens from assemblage of rare exotic mineral particles/grains; object sizes $~ 20-100 \mu \mathrm{m}$. Material separated from mid-punctata anomalous interval. A-I Mokrá, J-O Ochoz. • A - an example of a small spherule having a silicate nucleus, large pyrrhotite and hematite crystals close to or on the surface, and a devitrified-glass coating of approximately diopside composition, locally with adhering droplets. $\bullet$ B - other silicate/Fe-oxide spherule which is as a whole much more covered by devitrified glass ( $\mathrm{Si}$-Fe-Mg-Ca-Ti). The secondary minerals, bladed crystals and crystalline/ subcrystalline mixtures high in $\mathrm{Ba}$ and $\mathrm{Fe}$ crop out under the exfoliated surface. $\bullet \mathrm{C}-\mathrm{a}$ magnetite/hematite spherule with a pendant of $\mathrm{CAT}$ type mixture (= Ca-Al-Ti). Such mixture would be derived from melting of An-plagioclases high in Ti. Mineral of phlogopite composition and appearance, high in $\mathrm{Ba}$ and $\mathrm{Ti}$, is also present (left). $\bullet \mathrm{D}$ - silicate substance of $\pm \mathrm{CAT}$ composition was surrounded by ilmenite and pyrrhotite crystals, and finally by crystal plates of hematite. Arrangement of this hematite armour may indicate former ablation of molten surface. $\bullet$ E - surface of another magnetite spherule shows only small magnetite crystals $(1-2 \mu \mathrm{m})$ interlaced with $\mathrm{nm}-\mu \mathrm{m}$-sized diopsides. Rare diopside-like fragments locally remain adhering to the surface after chemical and ultrasonic treatment. $\bullet \mathrm{F}-$ a different spherule shows predominant pyrrhotite crystals, while still significant amounts of silicate and oxidic mixtures are between crystals, locally forming also inclusions. $\bullet \mathrm{G}-$ a contact of small pyroxene grain with a Fe-rich lamella structure (meshwork arranged crystals; \pm maghemite in present state, formerly ?iron and ?magnetite). $\bullet \mathrm{H}-$ devitrified fragment of a foam glass granule; pyroxene-like compositions of $\mathrm{Si}-\mathrm{Fe}-\mathrm{Mg}$ type, rich in Ti. • I - surface of onion-peel object, partly exfoliated. Some layers are sulphidic/oxidic (pyrrhotite/hematite predominate), other correspond to devitrified glass of pyroxene-like compositions, locally high in Ti, Ca. The uppermost layer consists of Fe-Mg glass and shows an apparent striation typical for melt globules after cooling in vapor (right). $\bullet \mathrm{J}-\mathrm{a}$ complex ferric/ferrous spherule with reduced content of sulfur (pyrrhotite, magnetite, hematite), low content of devitrified CAT-type glass. Note the small drops adhering to surface (upper left), and scars left by them (right, and down). $\bullet \mathrm{K}$ - fragment of pyroxene possesses laminae of phlogopite-like compositions and inclusions of barite. A piece of large spherule (upper left) most likely consists of delicately interlaced hematite and Si-Fe-Ca-type devitrified glass. $\bullet$ L - etched shard of devitrified/altered glass contains flakes of phlogopite and ilmenite compositions and appearances; structures relate to flow/plastic deformation in glass, preceding the decrepitation of objects. $\bullet \mathrm{M}$ - olivine grain with rounded, molten/ablated surface; the detail shows striation. $\bullet \mathrm{N}-$ another fragment of an exotic grain exemplifies a crystalline structure which consists of \pm diopside and hematite. Partly preserved surface (lower left) was also ablated. $\bullet \mathrm{O}-\mathrm{slightly}$ weathered olivine shows relicts of ablated surface (above), a conchoidal fracture (front), but also weathered mixture resembling chemically CAT-type glass precursors. Iron-rich parts (lower right) may contain relicts from pattern arrangements due to rapid cooling. 

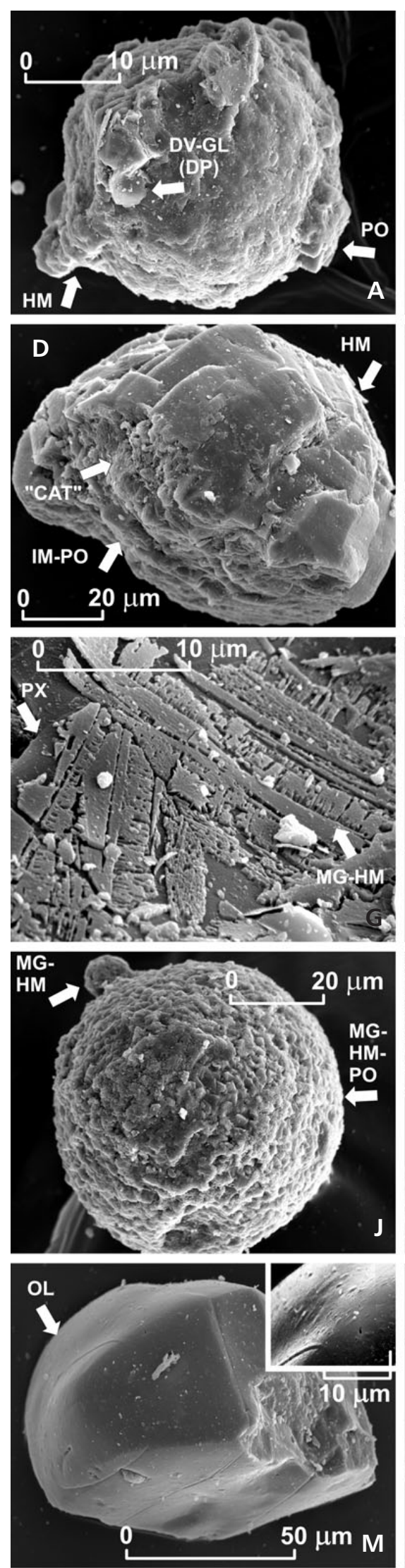
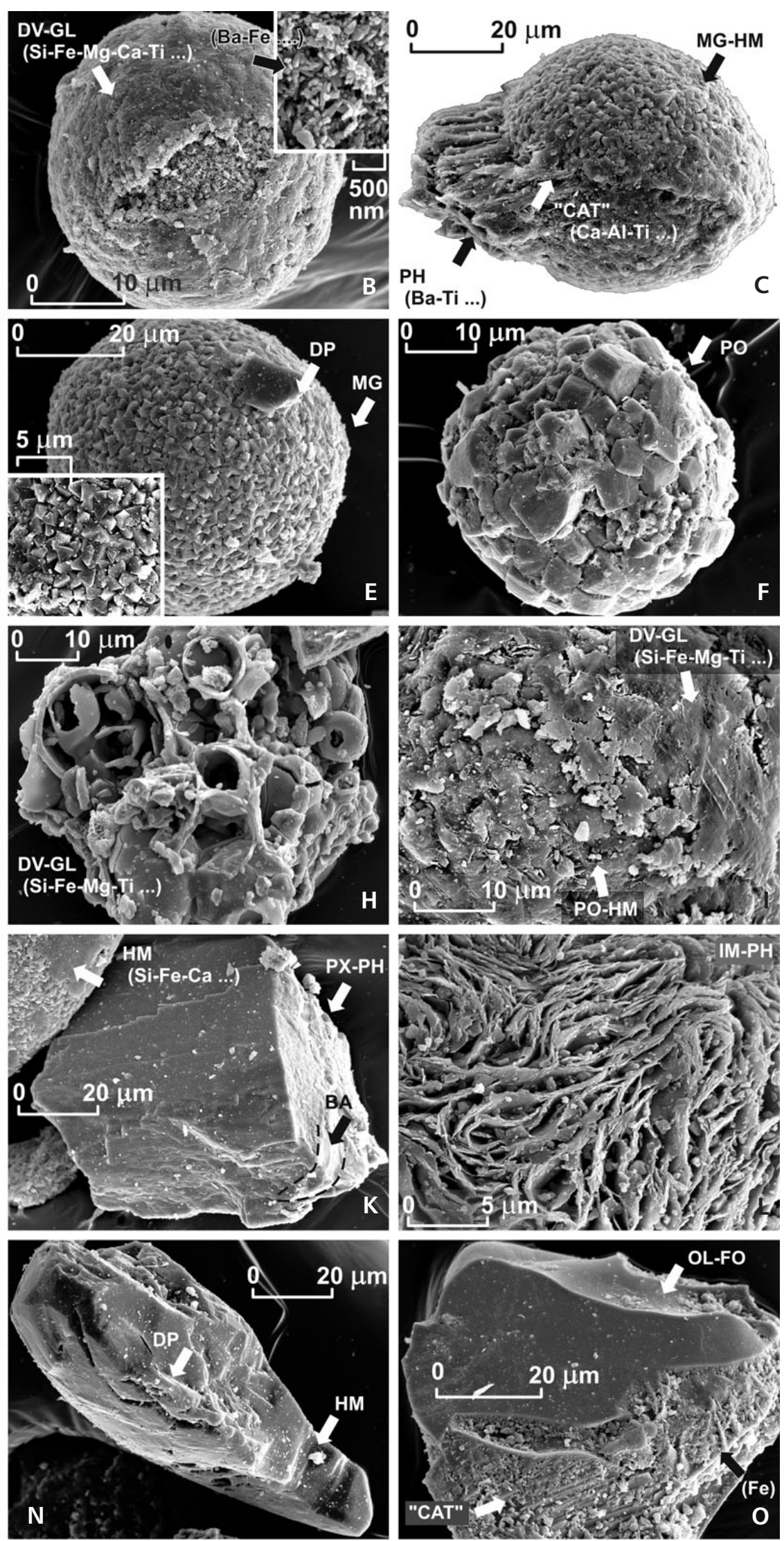
However, the magnetic, medium-heavy to heavy fractions provided a collection of really exotic grains. The mean extractable concentrations of these rare particles correspond approximately to $20-70 \mathrm{mg} / \mathrm{kg}$ (with estimated material loss not exceeding the level of $40 \%$ ). It is, very approximately, $1 / 100$ of all allochthonous relatively coarse particles and $1 / 1000$ of all non-carbonate impurities. The uncertainty in these proportions exists, of course, because there is a primarily biasing effect of irregularity on lenses, pockets, sutures and other spots where these materials were concentrated and/or reconcentrated in natural conditions, before sedimentation of the overlying late E-MF beds. The assemblage of separated exotic heavy grains (Fig. 9) contains iron-rich and silicate microspherules and drops, commonly with magnetite, hematite and pyrrhotite, having structures such as onion peels and striae on the surface. These grains are accompanied by devitrified glasses of An-rich plagioclase, diopside, and more complex compositions where the microscopical objects have fluid-plastic, wrinkled, and foam relict structures and are considerably rich in $\mathrm{Ti}$ and $\mathrm{Ba}$.

Fragments of well crystallized minerals or rocks are relatively less common but still important components. These correspond to olivines with ablation and striae on the surface of grains, plagioclases dotted with symplectic exsolutions, and pyroxenes with lamellae that contain iron-rich lamellae with rattan- or meteorite-iron-like arrangements of iron-oxide pseudomorphs after imperfectly identified original mineral phases. Phlogopites, and Ti-, Ba-, and Fe-enriched secondary minerals and their crystalline/subcrystalline mixtures form either separate lumps and pellets or coatings on 5-150 $\mu \mathrm{m}$ silt grains, average 55- $\mu \mathrm{m}$ (Fig. 9). This particular assemblage of grains may correspond to material upwells from the Earth's interior which was vigorously torn from the Earth surface, or, very speculatively, to olivine-phyric to basaltic and $\mathrm{Ni}$-, $\mathrm{Cr}$-depleted siderolite materials of possibly, although a little suspect, meteoritic origin.

These rare grain assemblages are roughly comparable between the Mokrá and Ochoz sections, although the latter provided slightly greater amounts of olivines and devitrified glasses. Recrystallized glassy materials contain fluid-plastic and visco-plastic structures. A number of these grains were considerably damaged by weathering and recrystallization, both during the processes of embedding and burial/exhumation diagenesis (Hladil 2001, Franců et al. 2002). However, there remained some grains with sufficiently preserved structures; these had to be surrounded by stable-composition blocky calcite crystal lattice of early diagenetic stage but having high resistance to fluids and recrystallization.

\section{Discussion}

Stratigraphic uncertainty persists. - To some degree, the application of local coral-stromatoporoid biostratigraphy must certainly be biased by the biofacies mosaics. In this context, two major aspects are worth mentioning: Firstly, the shallow ramp facies of Mokrá E-MF were exposed to immigration of young faunal elements, as can be exemplified by insertions of eastern species Amphipora tschussovensis or Scoliopora denticulata vassinoensis. It was combined with a considerable impoverishment of classical Old World Realm alveolitids. The fauna of the south Moravian Karst Horákov and Mokrá tectono-facies units was most likely influenced by the SE-European immigrants. The larval stages of calcareous skeleton-forming benthic organisms spread along the coasts or from island to island (Kalvoda 2001). It was considered as relevant to observed faunal change between the hassi and rhenana zones, but it started much earlier in the punctata zone. And secondly, the long-living and stable structures of the E-MF atoll-like structures (Ochoz) can serve as an example of an opposite reaction where the local communities were more resistant to immigrants' colonization: a limited number of them were successfully involved, but numerous conservative species and/or lineages survived.

It can be exemplified by the presence of corals similar to Disphyllum wirbelauense which are rooted deeply in Givetian-Frasnian communities. Another example of this type relates to Amphipora pervesiculata which repeatedly make insertions in lawns of much younger Amph. moravica. An exclusively biostratigraphic correlation, based on selected markers, works satisfactorily, with about 100-ka-related resolution, but area-related colonization mosaics have been a continuous source of problems (cf. Čejchan \& Hladil 1996 for the Devonian, or Budd \& Johnson 1999 for Pliocene-Pleistocene times).

Major climate-driven crises and bolide catastrophes: related or totally unrelated? - The interpretation of the mid-punctata record is also not free of problems. The inverse relationship between MS values and sedimentary system tracts can hardly be disproved due to strength of evidence in paleontological, microfacies and sedimentological data. However, the presence of such a pattern resembles a situation which often characterizes the major Devonian environmental events but not so frequently the events of secondary magnitude. With respect to opposite-tonormal relationships between sea level fluctuation and MS, mainly the Choteč, Kačák and Upper Kellwasser are examples of such a phenomenon where shallowing with a long-term reduction of eolian and riverine fluxes precedes strong flooding and delivery of detrital products.

The complete explanation of this structure of major events was possibly never provided, although many attempts to understand this were made (for example Hladil \& Kalvoda 1993, Geldsetzer et al. 1993, Morrow \& Sandberg 2003, Racki 2005; in combination with MS - Hladil et al. 2002, Hladil et al. 2008b). However, the concepts based on 
a relatively long pre-crisis development cannot reasonably describe the uniquely and subsequently triggered process (e.g., by the Alamo impactor).

This discrepancy between a $\sim 0.1$ Ma prologue and aftermaths of the same duration, in case of the other major crises with pre-crisis changes, and post-crisis syndromes lasting over several megayears, and bolide, or asteroid or cometary impact catastrophe somewhere in this interval may be attributable to two possibilities. Either the impact occurred randomly in such an interval, with possible 0.1-1 Ma frequency of such impacts, or the relatively long terrestrially driven crisis was systematically connected to extraterrestrial causes.

Such highly speculative distant causes must have long-term effects on ocean-atmospheric circulation and climatic settings. A strong secular fluctuation in energy provided by the Sun can speculatively be related to this. However, no serious evidence or models are available to explain sufficient change in the energy emission of the Sun or shading by meteoritic dust between Sun and Earth.

Middle Frasnian atmospheric load of mineral dust. - In spite of the great spatial extent of carbonate environments of Middle Givetian to Middle Frasnian times, the development of mixed carbonate-siliciclastic systems is not exceptional. The classical examples of carbonate ramps and reefs that were considerably resistant to stress from increased flux of terrigenous material were described from Belgium, W Canada or W Australia (Préat \& Kasimi 1995, Mabille \& Boulvain 2008, van Buchem et al. 1996, George et al. 1997). An almost absolute predominance of illite in argillaceous carbonate rocks of this time span was found in Belgium, e.g., in the Fromelennes unit. In wider stratigraphic ranges, for the Belgian Givetian-Frasnian limestones, the average abundances are: mica-illite $70 \%$, chlorite $16 \%$, smectite $7 \%$, corrensite (subregular chlorite-smectite mixed-layers) $4 \%$, kaolinite 2\% and random mixed-layers $1 \%$ (Han et al. 2000). The mica-illite and chlorite/chloritoide dominated impurities, with iron-oxyhydroxide and oxide components, were also transported to distant platform reefs where they sedimented in shallow water together with biological and recycled carbonate. It can be exemplified by pure carbonate systems, such as that of SE Moravia (Hladil et al. 2006a).

There is a reasonable expectation that the majority of this mica-illite, or locally illite-smectite material relates to mineralogical relicts of terrigenous material, although alterations by formation fluids exist in porous, e.g. bentonite layers (McCarty \& Reynolds 2001). The classical sedimentological concept emphasizes two dispersal sources, the input of terrigenous clastic dispersion along the coast line and from rivers. The first affects the inshore zone whereas the second contributes to along-shore and down slope dispersal. However, the long-living giant platform reef complexes are thriving in the places where these inputs are the lowest possible or at least considerably reduced.
Most coral reef growth is inhibited by sedimentary deposits from rivers. In addition, the shallowest water blanket which stretches over the wide platform reefs for hundreds of kilometres is not an appropriate medium for long distance dispersal of these primary aqueous suspensions because of flocculation and sedimentation.

On the other hand, it can be easy demonstrated, using the reviews on modern eolian dust distribution (Duce \& Tindale 1991, Tegen \& Fung 1995, Mahowald et al. 1999, Harrison et al. 2001, Zender et al. 2004), that the largest present-day carbonate complexes have a great supply of these deposits, which fluctuates in long-term averages from $1.5 \cdot 10^{-10}$ to $1.5 \cdot 10^{-9} \mathrm{~kg} \cdot \mathrm{m}^{-2} . \mathrm{s}^{-1}$ (i.e. $\sim 5$ to 50 tons per square meter and million years). It corresponds, assuming a $20 \mathrm{~m} / \mathrm{Ma}$ accumulation rate of pure carbonate, for example, to a maximum proportion of this non-carbonate component which is equal to $10-50 \%$. Although this material is washed and dissolved so that this amount is reduced roughly to $1 / 4$, it still represents $2.5-12.5 \%$ mass of limestone. Such amount is more than sufficient to explain the whole mass of embedded impurity, as the pure limestones of Quaternary platform reefs have generally been characterized by about $2-3 \%$ of this component.

The conclusion that develops from this comparison might help us understand the proportions between the typical aquatic and eolian inputs. On spacious and very shallow platform reefs, the dust delivery from eolian inputs must prevail. The dust-related impurity in pure limestone is identifiable by increased concentrations of iron which are equal or higher than those of potassium $(\mathrm{Fe} \geq \mathrm{K})$. Further, the iron oxides-oxyhydroxides and mica-illite are dominant mineral phases and all mineralogical variability is several times lower than in riverine input. And finally, the rare earth element (REE) distributions in atmospheric dust components display a minimum depletion of LREE in comparison with river mud.

The amounts of eolian dust trapped in modern platform reefs can reach 2 wt.\% of the limestone. Although it is only a rough emprical estimate of averaged impurity concentrations in off-shore reef sediments and uncertainty is high, from close to 0 to $4 \mathrm{wt}$. $\%$, the analyses from comparable reefs seem to confirm this traditional value (e.g., Crabbe $e t$ al. 2006). If we admit that duration of deposition on the platform reef area of the Moravian Karst was controlled mainly by the eolian dust delivery (Hladil et al. 2006a), then the E-MF impurity in limestone corresponds, also as a rough average for the figures, to $6 \mathrm{wt} \%$ of limestone. It indicates a significant difference (by a factor of 3 ).

Further estimates can be obtained from the masses of trapped and circulating dust. The recent calculations about mineral dust mass budgets (e.g., Luo et al. 2003, Tegen et al. 2004, Zender et al. 2004) keep the present-day annual emission (E) at about (rounded) $2000 \mathrm{Tg}$. [Marine salts are not involved, $c f$. Strier et al. 2006 for proportions today]. It 
may, most likely, be connected with turnover (mean residence) time $(\tau)$ of about 5-6 days and mean atmospheric burden $(M)$ of about $25-? 30 \mathrm{Tg}$. The simulated mechanism may account for a twofold to sixfold increase in dust concentration from interglacial to full glacial conditions (Greenland Ice Core Project; Andersen \& Ditlevsen 1998), with momentary peak values 100 times higher than today. It is hypothetized that mean Quaternary values may tentatively be set somewhat higher, perhaps about $E ? 3000 \mathrm{Tg}$, $\tau$ ?8 d, and $M$ ?50 Tg. From the experience with the 2007 Ukrainian dust event over the Europe, however, evidence suggests that these global estimates could be seriously underestimated (Hladil et al. 2008c). If we consider the $M$ parameters proportional to dust deposition and embedding in pure carbonate traps, which may not be completely correct, especially owing to still poorly known Devonian atmospheric conditions, then we can claim that the recorded impurity concentrations correspond to an approximately threefold higher E-MF burden ( $M$ ?150 Tg) in comparison to Quaternary. This estimate must be regarded together with the consequence of almost the highest (or at least very high) sea level stands during the whole Devonian (Morrow et al. 1995, Hladil 2002, not Johnson et al. 1985) when the far-reaching flooding over the continental shelf, coastal lowlands and cratonic peneplains, reduced the surface of emerged land. Thus, the land surface capability for emitting particulates was, most likely, several times more intensive, e.g., ?fivefold greater, than that of the Quaternary. With the E-MF interval, the several-10-ka averages may typically differ by a factor of 4 and those of about 100-ka by factor less than 2 based on the curves for mostly paramagnetic impurity in calcitic limestone (Fig. 7; or Hladil et al. 2006a, Nawrocki et al. 2008).

A few remarks on diagenetic alteration. - On the basis of the transmitted light microscopy and cathodoluminescence imaging, a rapid decrease in porosity of the E-MF limestone is seen. Production of isopachous cement with fibers or blades was much suppressed to completely absent, and the same was found for dog-tooth cement. Also dolomite is practically absent. The only exception to this rule is a slight tendency towards the production of early marine cement crusts that was coupled with insertions of relatively lightcoloured grainstone facies with Megalodont bivalves. After thin coating by bacterially-mediated precipitates, the molluscan shell fragments (bivalves, gastropods) were completely dissolved and replaced by equant calcite. The intergranular microporosity of packstones was rapidly filled due to calcite crystal growth nucleated on micrite to silt-sized particles, and the macropores were filled by medium-crystalline equant calcite. The filling by nonluminescent equant cement was rapid, as documented by occasionally observed, almost coeval intraclasts of grainstone-in-grainstone and fragments with replaced shells of molluscs. This rapid filling by stable-composition equant calcite is very typical for the E-MF, whereas the overlying Frasnian limestone, e.g., in the hassi zone, contains relicts of well-diversified successions of marine and meteoric calcite cements. The rapid early diagenetic drop in porosity, together with fills and recrystallizates of relatively stabilized pure-calcite compositions, strongly reduced the circulation of fluids. The risk to a chemically modified phase of phyllosilicates is not very high for these types of E-MF limestones, although the primary hydrated mica and illite-smectite impurity components were later thermally influenced and values of IC for Moravian Karst range typically from 0.44 to $0.55 \Delta 2^{\circ} \Theta$. These physico-chemical conditions during diagenesis differ from relatively porous and reactive carbonate-siliciclastic rocks (Han et al. 2000) or porous bentonites (McCarty \& Reynolds 2001).

After a 60 Ma period between the relevant ages in Frasnian and Serpukhovian, the strata were rapidly buried. Diffusive recrystallization in deep burial conditions encompassed both the allochems and cements but has an effect rather on microstructural change in orientation of calcite lattices of superimposed crystal mosaics than on dismembering (blurring) of primary carbonate microstructures and those of the embedded impurity. The porosity dropped to a minimum. Although the Serpukhovian-?Kasimovian deep-burial and early exhumation heating was exceptionally high, corresponding to temperatures of $150-250{ }^{\circ} \mathrm{C}$ (gradient from low to high is from SE to NW; Franců et al. 2002), the limited circulation of fluids in the impermeable microstructure of limestone is considered to have a low effect on impurity phases. The heating in these conditions may possibly have a minor effect on goethite-to-hematite transformation (Fan et al. 2006), and even the origination of pyrrhotite and magnetite from hypothetic thio-spinel precursors (Skinner et al. 1964), because the purely thermal transformation thresholds are above the maximum temperatures for these limestones. In addition, the E-MF rocks, in contrast to their relatively dark-grey colour have lesser amounts of diagenetic pyrrhotite and pyrite than other dark-grey intervals in the Moravian Karst. This seems to be in full agreement with MS and mineralogical data which suggest that mica-illite, with a few chlorite to chloritoid-bearing assemblages, and goethite, the most common paramagnetic impurities, prevail. Strong excursions based on occurrence of hematite or magnetite were not found. With respect to these aspects, we have considered the local E-MF conditions as quite favourable for studies on dust input.

\section{Conclusions}

Impurities in pure shallow-water limestones, from sequences without significant stratigraphical hiatuses, are princi- 
pally delivered onto the platform in the form of eolian or atmospheric deposition. The detailed exploration of these limestones has potential to explain circumstances of major global events and environmental crises. The level of the mid-punctata event recorded in limestones of the Moravian Karst platform reef is preceded by an interval which corresponds to low sea fall but, concurrently, also to steady-stable conditions with considerably reduced eolian and other detrital inputs. The abrupt rise in sea level marks the event base, and the event related beds are characterized by extremely high energy sedimentation, which is reduced upward, but still marked by the mixed carbonate and impurity material that was collected across the facies and with signs of material recycling.

A series of magnetic susceptibility stratigraphic measurements is indicative of the presence of an anomalous pattern in the middle of the early Middle Frasnian cycle ( punctata zone). This MS pattern consists of a pronounced low, followed by a composite high, that is first sharp at the base and gradually fades upward. This relatively robust and specifically shaped valley-and-peak segment in the MS plots was termed as A-B, and its stratigraphic correlation potential was assessed both in the terms of the regional and interregional correlation. The natural gamma-ray signal is high, both closely below and above the relevant flooding surface. The comparison of MS-GRS-INAA results was tested as an effective and promising approach in the search for coarser grains of atmospheric dust embedded in pure limestones.

A complex of separation and extraction techniques, with measures for monitoring possible contamination, was optimized for well cemented and slightly recrystallized pure limestones by maximum yield of suspect exotic particles. In sequentially separated heavy fractions, an assemblage of exotic silt- to fine-sand-sized grains $(5-150 \mu \mathrm{m})$ was found. The suspect assemblages contain a small but significant number of iron-rich silicate microspherules that have onion-like fabric and striated surfaces. Devitrified glasses of An-rich plagioclase, diopside and complex compositions are common. These give examples of fluid-plastic textures and contain also wrinkled and foamed varieties. The glassy materials are rich in $\mathrm{Ti}$ and $\mathrm{Ba}$, while $\mathrm{Cr}$ and $\mathrm{Ni}$ concentrations are relatively low. Fragments of minerals and rocks contain olivines, plagioclases, dotted with symplectic exsolutions, and pyroxenes. The ablated surfaces of olivine particles are often striated, and the pyroxene particles frequently host iron-rich lamellae. Phlogopites and various $\mathrm{Ti}, \mathrm{Ba}$, Fe-bearing secondary minerals are common in crystalline/subcrystalline pellets and coatings of smaller particles. Delivery of these suspect grains may most likely to have been connected with the Alamo impact catastrophe, although this single event cannot be the direct cause of the long-term and robust disturbances in the early Middle Frasnian.

\section{Acknowledgments}

The funding by the GA AS CR project IAAX00130702 and IAA300130702 on sedimentary mechanisms and rhythms, respectively, is gratefully appreciated, together with the frame project AV0Z30130516 on Earth system. D. J. Over, SUNY Geneseo, and A. Peterhänsel, Lukoil, helpfully provided critical comments on this study. Thanks also to F. Boulvain and A.-C. da Silva, University Liège, for cooperation and exchange of opinions on MS records and microfacies. Further thanks are due to keepers of outcrops: Českomoravský Cement Co., Lom Skalka Ochoz, Ltd. and Czech Speleological Society 6-14. And finally, the facilitating role of IGCP in correlation tasks is appreciated.

\section{Appendix}

Fields of co-authors' contribution are: L. Koptíková (Institute of Geology AS CR, v.v.i., Rozvojová 269, CZ-165 00 Praha), J. Otava (Czech Geological Survey, Branch Office Brno, Leitnerova 22, CZ-658 69 Brno; jiri.otava@geology.cz) and O. Bábek (Institute of Geological Sciences, Masaryk University, Kotlářská 2, CZ-611 37 Brno; babek@ sci.muni.cz) - lithology, sedimentary petrology; A. Galle (Institute of Geology AS CR, v.v.i., Rozvojová 269, CZ-165 00 Praha) - paleontology, paleogeography, biofacies; P. Pruner, P. Schnabl and M. Geršl (Czech Geological Survey, Branch Office Brno, Leitnerova 22, CZ-658 69 Brno) - geophysical records; J. Hladíková (Bohrova 1636, CZ-142 00 Praha 4; t.hladik@twobears.cz) - C and O isotopes; J. Frána (Nuclear Physics Institute AS CR, v.v.i., CZ-250 68 Rež; frana@ujf.cas.cz) - neutron activation analysis; V. Sedláček and A. Langrová (Institute of Geology AS CR, v.v.i., Rozvojová 269, CZ-165 00 Praha) - separation and determination of mineral phases.

\section{References}

ADEY, W.H. 1978. Coral reef morphogenesis: a multidimensional model. Science 202, 831-837.

DOI $10.1126 /$ science. 202.4370 .831

ANDERSEN, K.K. \& DitLEVSEN, P.D. 1998. Glacial/interglacial variations of meridional transport and washout of dust: A one-dimensional model. Journal of Geophysical Research 103, 8955-8962. DOI 10.1029/98JD00272

BÁBEK, O. 1996. Thinning and fining-upward megasequences in Middle Devonian carbonate slope deposits, Moravia, Czech Republic. Neues Jahrbuch für Geologie und Paläontologie, Abhandlungen 202, 409-432.

BÁBEK, O., PŘIKRYL, T. \& HLADIL, J. 2007. Progressive drowning of carbonate platform in the Moravo-Silesian Basin (Czech Republic) before the Frasnian/Famennian event: facies, compositional variations and gamma-ray spectrometry. Facies 53, 293-316. DOI 10.1007/s10347-006-0095-8

BÁBEK, O., TOMEK, Č., MElichar, R., KAlvoda, J. \& OtAVA, J. 2006. Structure of unmetamorphosed Variscan tectonic units of the southern Moravo-Silesian zone, Bohemian Mas- 
sif: a review. Neues Jahrbuch für Geologie und Paläontologie, Abhandlungen 239, 37-75.

BAte, G.L., HuizenGA, J.R. \& PotRATZ, H.A. 1959. Thorium in stone meteorites by neutron activation analysis. Geochimica et Cosmochimica Acta 16, 88-100. DOI 10.1016/0016-7037(59)90049-3

BosÁK, P., Mylroie, J.E., HLAdIL, J., CAREW, J.L. \& SLAVÍK, L. 2002. Blow Hole Cave: An unroofed cave on San Salvador Island, the Bahamas, and its importance for detection of paleokarst caves on fossil carbonate platforms. Acta Carsologica 31(3), 51-74.

Boulvain, F. 2001. Facies architecture and diagenesis of Belgian late Frasnian carbonate mounds. Sedimentary Geology 145, 269-294. DOI 10.1016/S0037-0738(01)00152-X

Boulvain, F. 2007. Frasnian carbonate mounds from Belgium: sedimentology and palaeoceanography. In ÁlVARO, J.J., ARetZ, M., Boulvain, F., Munnecke, A., VAchard, D. \& Vennin, E. (eds) Palaeozoic reefs and bioaccumulations: climatic and evolutionary controls. Geological Society of London, Special Publications 275, 125-142.

Boulvain, F. \& Coen-AuberT, M. 2006. A fourth level of Frasnian carbonate mounds along the south side of the Dinant Synclinorium (Belgium). Bulletin de l'Institut royal des sciences naturelles de Belgique, Sciences de la Terre 76, 31-51.

Boulvain, F., Da Silva, A.C., Mabille, C., Poulain, G., Hladil, J., GerŠL, M., KoptíkOVÁ, L. \& SCHNABL, P. 2008a. Magnetic susceptibility correlation of km-thick Eifelian-Frasnian sections (Belgium-Czech Republic). In KUNKel, C., HAHN, S., TEN VeEN, J., RAMEIL, N. \& IMMENHAUSER, A. (eds) $26^{\text {th }}$ Regional Meeting of the International Association of Sedimentologists (IAS) held jointly with the SEPM-CES SEDIMENT 2008 Meeting. Schriftenreihe der Deutschen Gesellschaft für Geowissenschaften 58, p. 57.

Boulvain, F., Mabille, C., Poulain, G. \& DA Silva, A.C. 2008b. Towards a palaeogeographical and sequential framework for the Givetian of Belgium. Geologica Belgica (in press).

Boulvain, F. \& Wood, R. 2007. Devonian. In Vennin, E., AretZ, M., Boulvain, F. \& MunNeCKe, A. (eds) Facies from Palaeozoic reefs and bioaccumulations. Mémoires $d u$ Museum national d'Histoire naturelle, Paris 195, 171-223.

BuDD, A.F. \& JOHNSON, K.G. 1999. Origination preceding extinction during late Cenozoic turnover of Caribbean reefs. Paleobiology 25, 188-200.

BUGGISCH, W. \& JOACHIMSKI, M.M. 2006. Carbon isotope stratigraphy of the Devonian of Central and Western Europe. In BugGisCH, W. (ed.) Evolution of the System Earth in the Late Palaeozoic: Clues from Sedimentary Geochemistry. Palaeogeography, Palaeoclimatology, Palaeoecology 240, 68-88.

BURCHETTE, T. 1981. European Devonian reefs: a review of current concepts and models. Society of Economic Paleontologists \& Mineralogists Special Publication 30, 85-142.

ČEJCHAN, P. \& HLADIL, J. 1996. Searching for extinction/recovery gradients: the Frasnian-Famennian interval, Mokrá Section, Moravia, central Europe. In HART, M.B. (ed.) Biotic recovery from mass extinction events. Geological Society of London, Special Publications 102, 135-161.
Cháb, J., Fišera, M., Fediuková, E., NovotnÝ, P., Opletal, M. \& SKÁCElovÁ, D. 1984. Problems of the tectonic and metamorphic evolution of the eastern part of the Hrubý Jeseník Mts. (Altvatergebirge), northern Moravia, Czechoslovakia. Sborník geologických věd, Geologie 39, 27-72. [in Czech]

COCKS, L.R.M. \& TORSVIK, T.H. 2005. Baltica from the late Precambrian to mid Palaeozoic: the gain and loss of a terranes's identity. Earth Science Reviews 72, 39-66.

DOI 10.1016/j.earscirev.2005.04.001

COPPER, P. 2002. Silurian and Devonian reefs: 80 million years of global greenhouse between two ice ages. In KIESSLING, W., FLÜGEL, E. \& GolONKA, J. (eds) Phanerozoic Reef Patterns. Society of Economic Paleontologists \& Mineralogists Special Publication 72, 181-238.

CRABbe, M.J.C., WILson, M.E.J. \& SMITH, D.J. 2006. Quaternary corals from reefs in the Wakatobi Marine National Park, SE Sulawesi, Indonesia, show similar growth rates to modern corals from the same area. Journal of Quaternary Science 21, 803-809. DOI 10.1002/jqs. 1001

Crick, R.E., Ellwood, B.B., Hladil, J., El Hassani, A., FEIST, R. \& HLADIL, J. 1997. Magnetosusceptibility event and cyclostratigraphy (MSEC) of the Eifelian-Givetian GSSP and associated boundary sequences in north Africa and Europe. Episodes 20(3), 167-175.

DARNLEY, A.G. 1991. The development of airborne gamma-ray spectrometry: case study in technological innovation and acceptance. Nuclear Geophysics 5(4), 377-402.

DA SiLVA, A.C. \& BoulvaIN, F. 2006. Upper Devonian carbonate platform correlations and sea level variations recorded in magnetic susceptibility. Palaeogeography, Palaeoclimatology, Palaeoecology 240, 373-388.

DOI 10.1016/j.palaeo.2006.02.012

Da Silva, A.C., Potma, K., WeissenberG, J.A.W., Whalen, M.T., Humblet, M., MABILle, C. \& Boulvain, F. 2008. Magnetic susceptibility evolution and sedimentary environments on carbonate platform sediments and atolls, comparison of the Frasnian from Belgium and from Alberta, Canada. Sedimentary Geology (in press). DOI 10.1016/j.sedgeo.2008.01.010

DuCE, R.A. \& TindaLE, N.W. 1991. Atmospheric transport of iron and its deposition in the ocean. Limnology and Oceanography $36,1715-1726$.

DUDEK, A. 1980. The crystalline basement block of the outer Carpathians in Moravia - Brunovistulicum. Rozpravy Československé akademie věd, ̌̌ada matematicko-př́rodních věd 90(8), 1-88.

DVOŘÁK, J. 1990. Paleofacial and paleoclimatic aspects of the Devonian and Carboniferous sedimentation in the Rhenohercynicum and Moravia. Věstník Českého geologického ústavu $65,65-74$.

DVOŘÁK, J. \& FRIÁKOVÁ, O. 1978. Paleozoic stratigraphy in neighbourhoods of Hranice n. M. Výzkumné práce Ústředního ústavu geologického 18, 5-50. [in Czech]

DVOŘÁK, Z., Kos, P., OTAVA, J. \& ŠIMíčEK, O. 2005. Svážná studna cave. Základní organizace České speleologické společnosti 6-14 Suchý Žleb, http://suchy-zleb.cz/jeskyne/svazna.php. [in Czech] 
EAKIN, C.M. 1996. Where have all the carbonates gone: a model comparison of calcium carbonate budgets before and after the 1982-1983 El Niño at Uva Island in the eastern Pacific. Coral Reefs 15, 109-119.

ECKHOFF, N.D., HILL, T.R. \& KIMEL, W.R. 1968. Trace element determinations by neutron activation analysis: theory and development. Transactions of the Kansas Academy of Science 71(2), 101-135. DOI 10.2307/3627363

EllwoOd, B.B., CRICK, R.E., El HASSANI, A., BENOIST, S.L. \& YOUNG, R.H. 2000. Magnetosusceptibility event and cyclostratigraphy method applied to marine rocks: detrital input versus carbonate productivity. Geology 28, 1135-1138. DOI 10.1130/0091-7613(2000)28<1135:MEACMA>2.0.CO;2

FAN, H., SONG, B. \& LI, Q. 2006. Thermal behavior of goethite during transformation to hematite. Materials Chemistry and Physics 98, 148-153.

DOI 10.1016/j.matchemphys.2005.09.005

FISCHBUCH, N.R. 1968. Stratigraphy, Devonian Swan Hills reef complexes of central Alberta. Bulletin of Canadian Petroleum Geology 16, 446-556.

Francu, E., Francuீ, J., Kalvoda, J., Poelchau, H.S. \& OTAVA, J. 2002. Burial and uplift history of the Palaeozoic Flysch in the Variscan foreland basin (SE Bohemian Massif, Czech Republic). In Bertotti, G., Schulmann, K. \& Cloetingh, S. (eds) Continental collision and the tectono-sedimentary evolution of forelands. European Geophysical Society, Stephan Mueller Special Publication Series 1, 259-278.

GALLE, A. 1985. Biostratigraphy and rugose corals of Moravian Devonian, Czechoslovakia. Newsletters on Stratigraphy 14(1), 48-68.

Galle, A., FriákovÁ, O., Hladil, J., KalvodA, J., KrejČí, Z. \& ZUKALOVÁ, V. 1988. Biostratigraphy of Middle and Upper Devonian carbonates of Moravia, Czechoslovakia. In MC-Millan, N.J., EMBRY, A.F. \& Glass, D.J. (eds) Devonian of the World, III. Canadian Society of Petroleum Geologists, Memoir 14(3), 633-645.

GALLE, A. 1985. Biostratigraphy and rugose corals of Moravian Devonian (Czechoslovakia). Newsletter on Stratigraphy 14, 48-68.

Galle, A., Hladil, J. \& IsAacson, P.E. 1995. Middle Devonian biogeography of closing south Laurussia-north Gondwana Variscides: examples from the Bohemian Massif (Czech Republic), with emphasis on Horní Benešov. Palaios 10, 221-239. DOI $10.2307 / 3515254$

Geldsetzer, H.H., Goodfellow, W.D. \& Mclaren, D.J. 1993. The Frasnian-Famennian extinction event in a stable cratonic shelf setting: Trout River, Northwest Territories, Canada. Palaeogeography Palaeoclimatology Palaeoecology 104, 81-95. DOI 10.1016/0031-0182(93)90121-X

George, A.D., Playford, P., POWEll, C.M. \& TORnAtora, P.M. 1997. Lithofacies and sequence development on an Upper Devonian mixed carbonate-siliciclastic fore-reef slope, Canning Basin, Western Australia. Sedimentology 44, 843-867. DOI 10.1046/j.1365-3091.1997.d01-52.x

GERŠL, M. \& HLADIL, J. 2004. Gamma-ray and magnetic susceptibility correlation across a Frasnian carbonate platform and the search for punctata equivalents in stromatoporoid-coral limestone facies of Moravia. Geological Quarterly 48(3), 283-292.

HAN, G., PRÉAt, A., ChAmley, H., DeCONINCK, J.F. \& MANSy, J.L. 2000. Palaeozoic clay mineral sedimentation and diagenesis in the Dinant and Avesnes Basins (Belgium, France): relationships with Variscan tectonism. Sedimentary Geology 136, 217-238. DOI 10.1016/S0037-0738(00)00103-2

HANŽL, P. \& MELICHAR, R. 1997. The Brno massif: a section through the active continental margin or a composed terrane? Krystalinikum 23, 33-58.

Harrison, S.P., Kohfeld, K.E., RoElandT, C. \& Claquin, T. 2001. The role of dust in climate changes today, at the last glacial maximum and in the future. Earth-Science Reviews 54, 43-80. DOI 10.1016/S0012-8252(01)00041-1

HAVLENA, V. 1976. Late Paleozoic paleogeography of Czechoslovakia and the Plzeň basin. Folia Musei Rerum Naturalium Bohemiae Occidentalis, Geologica 7, 1-31. [in Czech]

HLADIL, J. 1983. The biofacies section of Devonian limestones in the central part of the Moravian Karst. Sborník geologických věd, Geologie 38, 71-94.

HLADIL, J. 1986. Trends in the development and cyclic patterns of Middle and Upper Devonian buildups. Facies 15, 1-34. DOI $10.1007 / \mathrm{BF} 02536716$

HLADIL, J. 1988. Structure and microfacies of the Middle and Upper Devonian carbonate buildups in Moravia, Czechoslovakia. In MC-Millan, N.J., EMBRY, A.F. \& GLASS, D.J. (eds) Devonian of the World, II. Canadian Society of Petroleum Geologists, Memoir 14(2), 607-618.

HLADIL, J. 1994. Moravian Middle and Late Devonian buildups; evolution in time and space with respect to Laurussian shelf. Courier Forschungsinstitut Senckenberg 172, 111-125.

HLADIL, J. 2001. Changes of carbonate coral skeletons in deep burial and slight metamorphic conditions: eastern part of the Variscan Orogen in Europe. In EZAKI, Y., MORI, K., SUGIYAMA, T. \& SORAUF, J.E. (eds) Proceeding of the $8^{\text {th }}$ International Symposium on Fossil Cnidaria and Porifera, Sendai, 1999. Bulletin of the Tohoku University Museum 1, 173-186.

HLADIL, J. 2002. Geophysical records of dispersed weathering products on the Frasnian carbonate platform and early Famennian ramps in Moravia, Czech Republic: proxies for eustasy and palaeoclimate. Palaeogeography, Palaeoclimatology, Palaeoecology 181, 213-250.

DOI 10.1016/S0031-0182(01)00480-1

HLADIL, J. 2007. The Devonian MS-GRS reference section Moravian Karst: Upper Eifelian to uppermost Frasnian. Updated. http://home.gli.cas.cz/hladil/www/moravia-ms-grs-2005.htm

HLADIL, J. \& BEK, J. 1999. Distances between the Early/Middle Devonian Gondwana and Laurussia; faunal and spore dispersals as compared with paleomagnetic data on paleolatitudes. Exploration Geophysics, Remote Sensing and Environment 5, 2(1998), 29-33.

HLADIL, J., GERŠL, M., HLAdíKOVÁ, J. \& FRÁNA, J. 2004. Environmental disturbances in early Middle Frasnian (punctata Zone): Alamo Comet was likely accompanied by other bo- 
lides. Academy of Sciences CR, Institute of Geology, Annual Report 2003, 46-47, http://web.gli.cas.cz/annual/AnnRep2003.pdf.

HLADIL, J., GerŠL, M., STRnAd, L., FrÁnA, J., LANGROVÁ, A. \& SPIŠIAK, J. 2006a. Stratigraphic variation of complex impurities in platform limestones and possible significance of atmospheric dust: a study with emphasis on gamma-ray spectrometry and magnetic susceptibility outcrop logging (Eifelian-Frasnian, Moravia, Czech Republic). International Journal of Earth Sciences 95, 703-723. DOI $10.1007 / \mathrm{s} 00531-005-0052-8$

HLADIL, J. \& HLADÍKOVÁ, J. 2000. Isotopic compositions of carbon and oxygen in platform/reef carbonates of the Moravian Karst. In OSCHMANN, W., STEININGER, F.F. \& FÜRSICH, F.T. (eds) Biomarkers and Stable Isotopes in Palaeontology, European Palaeontological Association Workshop 2000, Senckenberg Museum, Frankfurt am Main 1, 51-53.

HLADIL, J. \& KALVODA, J. 1993. Extinction and recovery successions on the Devonian marine shoals: the Eifelian-Givetian and Frasnian-Famennian events in Moravia and Bohemia. Věstník Českého geologického ústavu 68(4), 13-23.

HLADIL, J., KOPTíKOVÁ, L., LISÁ, L., ČEJCHAN, P., RŮŽIČKA, M., KUlAVIAK, L., ADAMOVIČ, J., JANEČKA, J., VEČEŘ, M., DRAHOŠ, J. \& HAVLICA, J. 2008a. Stromatactis and stromatactum pattern formation in sediment: constraints from fluid mechanics and rheology and implications for environments, sedimentary architecture and cyclostratigraphy. In KIM, A.I., SAlimova, F.A. \& MeshChANKINA, N.A. (eds) International Conference Global Alignments of Lower Devonian Carbonate and Clastic Sequences, Kitab State Geological Reserve, Contributions, 36-40.

Hladil, J., KoptíkovÁ, L., RŮŽičKA, M. \& KulaviaK, L. 2007. Experimental effects of surfactants on the production of stromatactis-shaped cavities in artificial carbonate sediments. Bulletin of Geosciences 82(1), 37-50.

DOI 10.3140/bull.geosci.2007.01.37

Hladil, J., Melichar, R., Otava, J., Galle, A., Krs, M., Man, O., PRUNER, P., ČEJCHAN, P. \& OREL, P. 1999. The Devonian in the easternmost Variscides, Moravia; a holistic analysis directed towards comprehension of the original context. Abhandlungen der Geologischen Bundesanstalt in Wien 54, 27-47.

Hladil, J., Pruner, P., Venhodová, D., Hladilová, T. \& MAN, O. 2002. Toward an exact age of Middle Devonian Čelechovice corals: past problems in biostratigraphy and present solutions complemented by new magnetosusceptibility measurements. Coral Research Bulletin 7, 65-71.

HLADIL, J., RƯŽIČKA, M. \& KOPTÍKOVÁ, L. 2006b. Stromatactis cavities in sediments and the role of coarse-grained accessories. Bulletin of Geosciences 81(2), 123-146.

DOI 10.3140/bull.geosci.2006.02.123

HLADIL, J., Slavík, L., KoptíkovÁ, L., Schnabl, P., VACEK, F., BÁBEK, O. \& GERŠL, M. 2008b. Relationships between magnetic susceptibility of limestones and sea level change ('direct relationship and major crises on the Earth'). In Bjørlykke A. \& X-CD Technologies (eds) $33^{\text {rd }}$ International Geological Congress, Oslo, Abstract CD-ROM, p. 1343596.
HLADIL, J., STRNAD, L., ŠÁlEK, M., JANKOVSKÁ, V., ŠIMANDL, P., SCHWARZ, J., SMOLÍK, J., LISÁ, L., KOPTíKOVÁ, L., ROHOVEC, J., BÖHMOVÁ, V., LANGROVÁ, A., KOCIÁNOVÁ, M., MELICHAR, R. \& ADAMOVIČ, J. 2008c. An anomalous atmospheric dust deposition event over Central Europe, 24 March 2007, and fingerprinting of the SE Ukrainian source. Bulletin of Geosciences 83(2), 175-206.

DOI 10.3140/bull.geosci.2008.02.175

HLADÍKOVÁ, J., HLADIL, J. \& ZuSKOVÁ, J. 1997. Discrimination between facies and global controls in isotope composition of carbonates: carbon and oxygen isotopes at the Devonian reef margin in Moravia (HV-105 Krrtiny borehole). Journal of the Czech Geological Society 42, 1-16.

JANOUŠEK, V., HLADIL, J., FRÝDA, J. \& SLAVÍK, L. 2000. Strontium chemostratigraphy as an indicator of age and duration of reef sedimentation - a case study from Koněprusy reef of Pragian age, Devonian, central Bohemia. Journal of Conference Abstracts 5(2), 552.

JoHN, E.H., ClIFF, R. \& WignALL, P.B. 2008. A positive trend in seawater ${ }^{87} \mathrm{Sr} /{ }^{86} \mathrm{Sr}$ values over the Early-Middle Frasnian boundary (Late Devonian) recorded in well-preserved conodont elements from the Holy Cross Mountains, Poland. In RACKI, G., JOACHIMSKI, M.M. \& MORROW, J.R. (eds) A major perturbation of the global carbon budget in the Early-Middle Frasnian transition (Late Devonian). Palaeogeography, Palaeoclimatology, Palaeoecology (Special Issue) 269, 166-175.

JOHnSON, J.G., KlAPPER, G. \& SANDBERG, C.A. 1985. Devonian eustatic fluctuations in Euramerica. Geological Society of America Bulletin 96, 567-587.

DOI 10.1130/0016-7606(1985)96<567:DEFIE >2.0.CO;2

KALVODA, J. 2001. Upper Devonian-Lower Carboniferous foraminiferal paleobiogeography and Perigondwana terranes at the Baltica-Gondwana interface. Geologica Carpathica 52(4), 205-215.

Kalvoda, J., BÁBeK, O., FAtKa, O., Leichmann, J., MeliCHAR, R., NEHYBA, S. \& ŠPAČEK, P. 2008. Brunovistulian terrane (Bohemian Massif, Central Europe) from late Proterozoic to late Paleozoic: a review. International Journal of Earth Sciences 97, 497-518. DOI 10.1007/s00531-007-0183-1

Kalvoda, J., Melichar, R., BÁBEK, O. \& LEICHMANN, J. 2002. Late Proterozoic-Paleozoic tectonostratigraphic development and paleogeography of Brunovistulian terrane and comparison with other terranes at the SE margin of Baltica-Laurussia. Journal of the Czech Geological Society 47, 81-102.

Kalvoda, J., Leichmann, J., BÁbeK, O. \& Melichar, R. 2003. Brunovistulian terrane (central Europe) and Istanbul Zone (NW Turkey): Late Proterozoic and Paleozoic tectonostratigraphic development and paleogeography. Geologica Carpathica 54, 139-152.

Kiessling, W., FlÜGel, E. \& GolonkA, J. 1999. Paleoreef maps: evaluation of a comprehensive database on Phanerozoic reefs. American Association of Petroleum Geologists, Bulletin 83, 1552-1587.

KNOLL, G.F. 1989. Radiation detection and measurement. 754 pp. Wiley \& Sons, New York.

Kuncíř, J., BenAdA, J., ŘAndA, Z. \& VOBECKÝ, M. 1970. 
Multielement standard for routine instrumental activation analysis of trace elements in rocks and tektites. Journal of Radioanalytical Chemistry 5, 369-378.

DOI $10.1007 / \mathrm{BF} 02513854$

LEIPUNSKAYA, D.I., GAUER, Z.E. \& Flerov, G.N. 1960. Neutron activation analysis of samples of rock and ore concentrates. Atomic Energy 6(3), 198-202. DOI $10.1007 / \mathrm{BF} 01481454$

LuO, C., MAHOWALD, N.M. \& DEL CORRAL, J. 2003. Sensitivity study of meteorological parameters on mineral aerosol mobilization, transport, and distribution. Journal of Geophysical Research 108, 4447. DOI 10.1029/2003JD003483

MA, X.-P., WANG, C.-Y., RACKI, G. \& RACKA, M. 2008. Facies and geochemistry across the Early-Middle Frasnian transition (Late Devonian) on South China carbonate shelf: Comparison with the Polish reference succession. In RACKI, G., JOACHIMSKI, M.M. \& MORROW, J.R. (eds) A major perturbation of the global carbon budget in the Early-Middle Frasnian transition (Late Devonian). Palaeogeography, Palaeoclimatology, Palaeoecology (Special Issue) 269, 130-151.

MABILle, C. \& Boulvain, F. 2008. Les monts de Baileux section: detailed sedimentology and magnetic susceptibility of Hanonet, Trois-Fontaines and Terres d'Haurs formations (Eifelian/Givetian boundary and Lower Givetian, SW Belgium). Geologica Belgica 11, 93-121.

MAHOWALD, N., KOHFELD, K.E., HANSSON, M., BALKANSKI, Y., HARrison, S.P., PRENTICE, I.C., RodHe, H. \& SCHUlZ, M. 1999. Dust effect of climate change on dust storm activity in Australia during the Last Glacial Maximum. Geomorphology 17, 263-271.

MCCARTY, D.K. \& REYNOLDS, R.C. 2001. Three-dimensional crystal structures of illite-smectite minerals in Paleozoic K-bentonites from the Appalachian basin. Clays and Clay Minerals 49, 24-35. DOI 10.1346/CCMN.2001.0490102

MIKULÁŠ, R. 1994. Sponge borings in stromatoporoids and tabulate corals from the Devonian of Moravia (Czech Republic). Věstník Českého geologického ústavu 69, 69-73.

MORROW, J.R., RACKI, G. \& MALKOWSKI, K. 2003. Timing of Frasnian (early Late Devonian) carbon isotopic and Alamo impact events, Southern Nevada. Annual Meeting, Geological Society of America, Seattle, Washington, Abstracts with Programs 35(6), 209.

Morrow, J.R. \& SANDBERG, C.A. 2003. Late Devonian sequence and event stratigraphy across the Frasnian-Famennian (F-F) boundary, Utah and Nevada, 351-419. In HARRIES, P.J. (ed.) High-resolution approaches in stratigraphic paleontology. Kluwer, Dordecht. DOI 10.1007/978-1-4020-9053-0_10

Morrow, J.R., SANDBERG, C.A. \& HARris, A.G. 2005. Late Devonian Alamo Impact, southern Nevada, USA: Evidence of size, marine site, and widespread effects, Chap. 15. In KENKMANN, T., HÖRZ, F., \& DEUTSCH, A. (eds) Large Meteorite Impacts III. Geological Society of America Special Paper 384, $259-280$.

Morrow, J.R. (ed.), SANDBERG, C.A., WARME, J.E., MurPhy, M.A. \& OVER, D.J. 2007. Devonian shelf-to-slope facies and events, Central Great Basin, Nevada and Utah, U.S.A.
Subcommission of Devonian Stratigraphy SDS 2007 field trip Guidebook, 93 pp. Eureka, Nevada.

MORROW, J.R., SCHINDLER, E. \& WALLISER, O.H. 1995. Phanerozoic development of selected global environmental features, 53-61. In WALLISER, O.H. (ed.) Global events and event stratigraphy in the Phanerozoic. Springer Verlag Berlin.

MoXHAM, R.M., FoOTE, R.S. \& BUNKER, C.M. 1965. Gamma ray spectrometer studies of hydrothermally altered rocks. Economic Geology 60, 653-671.

NARKIEWICZ, M. 2007. Development and inversion of Devonian and Carboniferous basins in the eastern part of the Variscan foreland (Poland). Geological Quarterly 51, 231-256.

NAwrocki, J., Polechońska, O. \& Werner, T. 2008. Magnetic susceptibility and selected geochemical-mineralogical data as proxies for Early to Middle Frasnian (Late Devonian) carbonate depositional settings in the Holy Cross Mountains, southern Poland. In RACKI, G., JOACHIMSKI, M.M. \& MORROW, J.R. (eds) A major perturbation of the global carbon budget in the Early-Middle Frasnian transition (Late Devonian). Palaeogeography, Palaeoclimatology, Palaeoecology (Special Issue) 269, 176-188.

NAWrocki, J., ZYLINSKA, A., BULA, Z., GraBOwSKI, J., KRZYWIEC, P. \& POPRAWA, P. 2004. Early Cambrian location and affinities of the Brunovistulian terrane (Central Europe) in the light of palaeomagnetic data. Journal of the Geological Society of London 161, 513-522.

OtAVA, J. \& KAHLE, V. 2003. Svážná studna cave in the Lažánecký žleb valley: genesis and hydrographic situation. Speleoforum, Czech Speleological Society 22, 5-7. [in Czech]

PERRY, C.T., SPENCER, T. \& KENCH, P.S. 2008. Carbonate budgets and reef production states: a geomorphic perspective on the ecological phase-shift concept. Coral Reefs 27, 853-866. DOI 10.1007/s00338-008-0418-z

PINTO, J.A. \& WARME, J.E. 2008. Alamo Event, Nevada: Crater stratigraphy and impact breccia realms. In EvANS, K.R., HoRTON, J.W., JR., KING, D.T., JR. \& MORROW, J.R. (eds) The sedimentary record of meteorite impact events. Geological Society of America Special Paper 437, 99-137.

Pisarzowska, A., Sobstel, M. \& RACKI, G. 2006. Conodont-based event stratigraphy of the Early-Middle Frasnian transition on the South Polish carbonate shelf. Acta Palaeontologica Polonica 51, 609-646.

PRÉAT, A. \& KASIMI, R. 1995. Sédimentation de rampe mixte silico-carbonatée des couches de transition eifeliennesgivetiennes franco-belges. Première partie: microfaciès et modèle sédimentaire. Bulletin des Centres de Recherche Exploration-Production Elf Aquitaine 19, 329-375.

RACKI, G. 1993. Evolution of the bank to reef complex in the Devonian of the Holy Cross Mountains. Acta Paleontologica Polonica 37, 87-182.

RACKI, G. 2005. Toward understanding Late Devonian global events: few answers, many questions. In OVER, J., MORROW, J. \& Wignall, P.B. (eds) Understanding Late Devonian and Permian-Triassic biotic and climatic events: towards an integrated approach. Developments in Paleontology and Stratigraphy 20, 5-36. 
RACKI, G., JOACHIMSKI, M.M. \& MORROW, J.R. 2008. A major perturbation of the global carbon budget in the Early-Middle Frasnian transition (Late Devonian). Preface. In RACKI, G., JOACHIMSKI, M.M. \& MORROW, J.R. (eds) A major perturbation of the global carbon budget in the Early-Middle Frasnian transition (Late Devonian). Palaeogeography, Palaeoclimatology, Palaeoecology (Special Issue) 269, 127-129.

ŘAnda, Z., FrÁNA, J., Mizera, J., KuČERA, J., NOVÁK, J.K., ULRYCH, J., BELOV, A.G. \& MASLOV, O.D. 2007. Instrumental neutron and photon activation analysis in the geochemical study of phonolitic and trachytic rocks. Geostandards and Geoanalytical Research 31, 275-283. DOI 10.1111/j.1751-908X.2007.00839.x

RAANDA, Z. \& KREISINGER, F. 1983. Tables of nuclear constants for gamma-activation analysis. Journal of Radioanalytical Chemistry 77, 279-495. DOI 10.1007/BF02522230

REISINGER, J. \& HuBMANN, B. 1998. Outcrop gamma-ray logging of Devonian shallow marine deposits: examples from the Graz Paleozoic, Austria. Carpathian-Balkan Geological Association XVI, Congress Abstracts, Vienna, 515.

RUFFELL, A. \& WORDEN, R. 2000. Palaeoclimate analysis using spectral $\gamma$-ray data from the Aptian (Cretaceous) of southern England and southern France. Palaeogeography, Palaeoclimatology, Palaeoecology 155, 265-283. DOI 10.1016/S0031-0182(99)00119-4

SKINNER, B.J., ERD, R.C. \& GRIMALDI, F.S. 1964. Greigite, the thio-spinel of iron; a new mineral. Journal of the Mineralogical Society of America 49(5-6), 543-555.

STAMPFLI, G.M. \& BOREL, G. 2004. The TRANSMED transects in time and space, 53-80. In CAVAZZA, W., Roure, F., SPAKMAN, W., STAMPFLI, G.M. \& ZieGLER, P.A. (eds) The TRANSMED Atlas: The Mediterranean Region from Crust to Mantle. Springer Verlag, Berlin.

Stier, P., Feichter, J., RoECKNER, E., Kloster, S. \& Esch, M. 2006. The evolution of the global aerosol system in a transient climate simulation from 1860 to 2100. Atmospheric Chemistry and Physics 6, 3059-3076.

Strnad, L., EtTler, V., Mihaljevič, M. \& Hladil, J. 2008. Trace elements in landfill calcite: a comparison of solution \& laser ablation ICP-MS and calibration to different standard material (SRM NIST glass and USGS MACS carbonate). In BAulus-LÁZARo, B. (ed.) Comunicaciones de la XXVIII Reunión de la Sociedad Española de Mineralogía. La revista Macla 9, 235-236.

TAPANILA, L. 2006. Macroborings and bioclaustrations in a late Devonian reef above the Alamo impact breccia, Nevada, USA. Ichnos 13, 129-134. DOI 10.1080/10420940600850893

TEGEN, I. \& FUNG, I. 1995. Contribution to the atmospheric mineral aerosol load from land surface modification. Journal of Geophysical Research 100, 18707-18726.

DOI 10.1029/95JD02051

Tegen, I., Werner, M. HARrison, S. \& KoHFEld, K. 2004. Relative importance of climate and land use in determining present and future global soil dust emission. Geophysical Research Letters 31, L05105. DOI 10.1029/2003GL019216

VAN BUCHEM, F.S.P., EBERLI, G.P., WHALEN, M.T., MOUNTJOY, E.W. \& HOMEWOOD, P.W. 1996. The basinal geochemical signature and platform margin geometries in the Upper Devonian mixed carbonate-siliciclastic system of western Canada. Bulletin de la Société Géologique de France 167, 685-699.

VIEREK, A. 2007. Transitional reef-to-basin facies of Lower Frasnian limestones determined by microfacies analysis (Wietrznia, Holy Cross Mts, Poland). Facies 53, 141-155. DOI $10.1007 / \mathrm{s} 10347-006-0079-8$

WARME, J.E. \& SANDBERG, C.A. 1995. The catastrophic Alamo Breccia of southern Nevada: Record of a Late Devonian extraterrestrial impact: Courier Forschungsinstitut Senckenberg $188,31-57$.

WARME, J.E. \& SANDBERG, C.A. 1996. Alamo megabreccia: Record of a Late Devonian impact in southern Nevada. GSA Today 6(1), 1-7.

Whalen, M.T., EBERLI, G.P., VAN BUCHEM, F.S.P. \& MOUNTJOY, E.W. 2000. Facies models and architecture of Upper Devonian carbonate platforms (Miette an Ancient wall), Alberta, Canada. In Homewood, P.W. \& EBERLI, G.P. (eds) Genetic Stratigraphy on the Exploration and the Production Scales. Case Studies from the Pennsylvanian of the Paradox Basin and the Upper Devonian of Alberta. Bulletin des Centres de Recherches et d'Exploration-Production, Elf-Aquitaine, Mémoire 24, 139-178.

WHALEN, M.T. \& DAY, J.E. 2005. Magnetic susceptibility, biostratigraphy, and sequence stratigraphy: insights into Devonian carbonate platform development and basin infilling, western Alberta. American Association of Petroleum Geologists Annual Convention Abstracts 14, A151.

Winchester, J.A., PHARAOH, T.C. \& VERniers, J. 2002. Palaeozoic amalgamation of Central Europe: an introduction and synthesis of new results from recent geological and geophysical investigations. In WINCHESTER, J.A., PHARAOH, T.C. \& VERNIERS, J. (eds) Palaeozoic amalgamation of Central Europe. Geological Society of London, Special Publications 201, 1-18.

WrZOLEK, T. 1992. Rugose corals from the Devonian Kowala Formation of the Holy Cross Mountains. Acta Palaeontologica Polonica 37, 217-254.

YANS, J., CORFIELD, R.M., RACKI, G. \& PRÉAT, A. 2007. Evidence for perturbation of the carbon cycle in the Middle Frasnian punctata Zone (Late Devonian). Geological Magazine 144, 263-270. DOI 10.1017/S0016756806003037

ZAPLETAL, K. 1931. Position of the Moravosilesian land in Variscides and Alpides. Sborník Přirodovědecké společnosti v Moravské Ostravě 6, 257-292. [in Czech]

ZENDER, C.S., MiLleR, R.L. \& TEgEN, I. 2004. Quantifying mineral dust mass budgets: Terminology, constraints, and current estimates. Eos 85(48), 509-512.

DOI $10.1029 / 2004 \mathrm{EO} 480002$

ZUKALOVÁ, V. 1980. Stromatoporoids in the Devonian carbonate complex in Moravia (Czechoslovakia). Acta Palaeontologica Polonica 25, 671-679. 